\title{
Spectroscopic and Functional Characterization of Nitrophorin 7 from the Blood-Feeding Insect Rhodnius prolixus Reveals an Important Role of Its Isoform-Specific N-Terminus for Proper Protein Function†
}

\author{
Markus Knipp ${ }^{\star} \ddagger$, Fei Yang, Robert E. Berry, Hongjun Zhang, Maxim N. Shokhirev, and F. Ann \\ Walker \\ Department of Chemistry, The University of Arizona, 1306 East University Boulevard, Tucson, AZ \\ 85721-0041, USA
}

\section{Abstract}

Nitrophorins (NPs) are a class of NO transporting and histamine sequestering heme $b$ proteins that occur in the saliva of the bloodsucking insect Rhodnius prolixus. A detailed study of the newly described member, NP7, is presented herein. NP7 NO association constants $K_{\text {eq }}^{\mathrm{III}}(\mathrm{NO})$ reveal a drastic change when the $\mathrm{pH}$ is varied from 5.5 (reflecting the insect's saliva) to slightly above plasma $\mathrm{pH}$ (7.5) ( $\left.>10^{9} \mathrm{M}^{-1} \rightarrow 4.0 \times 10^{6} \mathrm{M}^{-1}\right)$; thus, the protein promotes the storage of NO in the insect's saliva and its release inside the victim's tissue. In contrast to the other nitrophorins NP1-4, histamine sequestering cannot be accomplished in vivo due to the low binding constant $K_{\text {eq }}^{\mathrm{III}}($ histamine $)=10^{5}$ $\mathrm{M}^{-1}$ compared to [histamine] $=1-10 \times 10^{-9} \mathrm{M}$ in the blood. A major part of this study deals with the N-terminus ${ }^{1}$ Leu-Pro-Gly-Glu-Cys ${ }^{5}$ of NP7, which is not found in NP1-4. Since NP7 has not been isolated from the insects so far, but was recognized in a cDNA library instead, the N-terminal site of signal peptidase cleavage upon protein secretion was predicted by the program SIGNALP [Andersen, J.F., Gudderra, N.P., Francischetti, I.M.B., Valenzuela, J.G., Ribeiro, J.M.C. (2004) Biochemistry 43, 6987-6994]. In marked contrast to wild-type NP7, NP7( $\Delta 1-3)$ shows a very high NO-affinity at $\mathrm{pH} 7.5\left(K_{\mathrm{eq}}^{\mathrm{III}}(\mathrm{NO}) \approx 10^{9} \mathrm{M}^{-1}\right)$, suggesting that the release of $\mathrm{NO}$ in the plasma cannot efficiently be accomplished by the truncated form. Comparison of the reduction potentials of both constructs by spectroelectrochemistry revealed an average increase of $+85 \mathrm{mV}$ for various distal ligands bound to the heme-iron when ${ }^{1}$ Leu-Pro-Gly ${ }^{3}$ was removed. However, ${ }^{1} \mathrm{H}$ NMR and EPR spectroscopy show that the electronic properties of the $\mathrm{Fe}^{\mathrm{III}}$ cofactor are similar in both wild-type NP7 and NP7( $\Delta 1-3)$. Further, thermal denaturation that revealed a higher stability of wild-type NP7 compared to NP7 $(\Delta 1-3)$, in combination with a homology model based on the NP2 crystal structure $($ RMSD $=0.39 \AA)$, suggest that interaction of the ${ }^{1}$ Leu-Pro-Gly ${ }^{3}$ peptide with the A-B and/or G-H loops is key for proper protein function.

\footnotetext{
${ }^{\dagger}$ This work was financially supported by the Swiss National Science Foundation (SNF), grant PA00A--109035 (to M.K.), and by the National Institutes of Health (NIH), grant HL54826 (to F.A.W.).

‡Future address: Max Planck Institute for Bioinorganic Chemistry, Stiftstrasse 34-36, D-45470 Mühlheim an der Ruhr, Germany. *Corresponding author: Tel: +1-520-621-9697; Fax: +1-520-621-8407; E-mail: mknipp@email.arizona.edu.

Supporting Information Available: Figure S1, angle plot for low-spin ferrihemes. This material is available free of charge via the Internet at http://pubs.acs.org.
} 


\section{Keywords}

5-coordinate heme-NO; lipocalin; nitric oxide; nitrophorin; Rhodnius prolixus

The 'kissing bug' Rhodnius prolixus is an important vector of Chagas' disease, one of the world's most wide-spread lethal diseases transmitted by blood-sucking insects $(1,2)$. The insect spreads the protozoan Trypanosoma cruzi, a parasite living in the insect's gut, through defecation at the site of the bite (3). A death toll of 15,000 persons per year from this disease was reported in 2004 according to $\mathrm{WHO},{ }^{1}$ and there are probably many more victims for whom the disease was not diagnosed. The overwhelming majority of infected persons (16-18 million people) live in South and Central America (2) but the disease has, however, migrated as far North as the Southern United States, including California, Arizona, and Texas, which puts many more people at risk of infection $(4,5)$. This situation led to the careful investigation of the biology and physiological processes involved in the vector $\leftrightarrow$ host interaction.

The nitrophorins $(\mathrm{NPs})^{2}$ represent a group of NO-carrying heme proteins found in the saliva of $R$. prolixus (6), which in its adult phase expresses at least four nitrophorins, designated NP1 to NP4 in order of their decreasing abundances in the saliva of adult insects $(1,7)$. Before $R$. prolixus reaches the adult phase it develops through five instar nymphal stages (3). Two additional nitrophorins, designated NP5 and NP6, have been detected mainly in the five instar nymphal stages of the insect development (8). Nitrophorins are expressed in the endothelial cells of the salivary gland where an $\mathrm{N}$-terminal signal sequence leads them to be secreted before it is truncated. After the salivary glands are loaded with nitrophorins, a nitric oxide synthase (NOS) in the endothelium is turned on and charges the nitrophorin heme $b$ cofactor with NO (9-11). The low $\mathrm{pH}$ of the saliva (5 - 6) (12) stabilizes the Fe $\mathrm{Fe}^{\mathrm{III}}-\mathrm{NO}$ complex (13). In contrast to other heme proteins, e.g., myoglobin (Mb), which are reduced by excess $\mathrm{NO}(14)$, nitrophorins stabilize the $\mathrm{Fe}^{\mathrm{III}}$ state by having a number of carboxylates near the heme pocket (Berry, Shokhirev, Ho, Zhang, and Walker, to be submitted) and a ruffled heme geometry which is induced mainly by two Leu side chains that point toward the distal side of the heme (15). This way, the reduction potential is established at, e.g., $-303 \mathrm{mV} v s$. SHE at $\mathrm{pH} 7.5$ for $\mathrm{NP} 1$ compared to $\sim 0 \mathrm{mV} v s$. SHE for Mb (16). This is important for nitrophorin function

because $\mathrm{Fe}^{\mathrm{II}}-\mathrm{NO}$ association constants are too large to allow sufficient $\mathrm{NO}$ release $\left(K_{e q}^{I I}(\mathrm{NO})\right.$ $\left.=10^{13}-10^{14} \mathrm{M}^{-1}\right)(17)$.

When the blood-sucker feeds on a victim, the insect pumps the saliva in boluses with a mean frequency of $0.51 \mathrm{~Hz}$ into the victim through the saliva canal while pumping out the victim's blood through the feeding canal at the same time $(2,12)$. The drastic $\mathrm{pH}$ change to that of the blood plasma $(\sim 7.4)$ induces conformational change in the nitrophorin structure that decreases the NO affinity $1-2$ orders of magnitude and concomitantly leads, together with the large dilution (estimated to be a factor of 100 in the tissues, but would be more in the blood stream), to the release of NO.

$\mathrm{NO}$ acts as a vasodilator and a platelet aggregation inhibitor, from both of which the insect profits during feeding. In addition, the imidazole group of histamine $(\mathrm{Hm})$, which is released from mast cells at the site of the bite as an immune stimulus (18), binds to the open coordination

\footnotetext{
${ }^{1}$ World Health Report 2004, http://www.who.int/tdr/diseases/default.htm.

2 Abbreviations: DEA/NO, sodium (Z)-1-(N,N-diethylamino)diazen-1-ium-1,2-diolate; Hm, histamine; HMM, hidden Markov model; HSA, human serum albumin; ImH, imidazole; L, distal ligand on heme iron; MALDI, matrix assisted laser desorption ionization; Mb, myoglobin; MOPS, 3-( $N$-morpholino)propanesulfonic acid; NN, neuronal network; NOS, nitric oxide synthase; NP, nitrophorin; $\mathrm{pH}^{*}$, ' $\mathrm{pH}$ ' in $\mathrm{D}_{2} \mathrm{O}$ solutions uncorrected for the deuterium effect; PS, L- $\alpha$-phosphatidyl-L-serine; sGC, soluble guanylate cyclase; SHE, standard hydrogen electrode; SNAP, $S$-nitroso- $N$-acetyl-D,L-penicillamine; TOF, time-of-flight; $w t$, wild type.
} 
site of the iron; thus, $R$. prolixus nitrophorins act as histamine traps and contribute to the immune response suppression (19) during the time of feeding $(10-30 \mathrm{~min})(2,3)$.

NP1-4 have been investigated by a number of spectroscopic techniques $(15,16,20-27)$, spectroelectrochemistry $(1,15,16,21,28)$, and stopped-flow kinetics (28-30), and the solid-state structures of several ligand complexes of NP1 (16,31), NP2 (32), (Weichsel, Berry, Walker \& Montfort, to be submitted) and NP4 (30,33-35) have been determined by X-ray crystallography. The structures are unique for heme proteins, in that the heme is located at the open end of a $\beta$-barrel (36), rather than in the more commonly observed largely $\alpha$-helical globin or four-helix bundle folds. The ferriheme prosthetic group is bound to the protein via a His ligand, leaving the sixth coordination site available to bind NO or other ligands.

Another nitrophorin (NP7) has recently been found in a cDNA library generated from salivary glands of $\mathrm{V}^{\text {th }}$ instar nymphs $(37,38)$ but the protein has never been isolated from the insects. Of all the $R$. prolixus NPs discovered, NP7 is especially interesting since it was found to bind to $\mathrm{L}-\alpha$-phosphatidyl-L-serine (PS) containing phospholipid membranes which NP1-4 do not do $(38,39)$. In platelets and mast cells, the loss of membrane asymmetry, which leads to the display of PS on the outer surface, is rapid and tightly coupled with other activation events, making it a highly reliable indicator of hemostatic activity and degranulation. NP1-4 would, therefore, remain in solution, diffusing away from the feeding site while releasing $\mathrm{NO}$ over a larger area. Recognition of PS exposure by proteins is important in biological processes such as the assembly of coagulation complexes and the clearance of apoptotic cells by macrophages (40, 41). Thus, NP7 recognizes PS-bearing membrane surfaces as an indicator of activation and uses this as a means of targeting the surfaces of activated platelets and degranulating mast cells. Once bound on an activated platelet, NP7 can release NO to inhibit platelet aggregation and act as an anticoagulant by blocking coagulation-factor binding sites.

NO is highly reactive in a biological environment $\left(t_{1 / 2} \approx 100 \mathrm{~ms}\right.$ in blood $\left.(42)\right)$, but is protected from oxidation when bound to NPs (16). Targeted delivery to activated surfaces at the point of feeding may enhance the activity of NP7 as a platelet aggregation inhibitor by delivering NO in a protected form to its site of action and preventing its removal from the feeding area by diffusion and blood flow.

Although NP1-4 have been extensively studied and are structurally well-characterized, it remains a matter of debate why $R$. prolixus uses a whole bundle of NPs instead of just one, as seems to be the case with Cimex lectularius (the bedbug) (43). In addition, it remains unclear why the six life stages of $R$. prolixus (five instar nymphs and the adult stage) use different expression patterns of NPs (8). To answer this question, comparative investigations of all NPs are required. Furthermore, we want to understand the properties of NP7 as a unique NO delivery system to cell surfaces, and thus the characterization of NP7 properties in comparison to the established NP1-4 is a necessary step.

\section{EXPERIMENTAL PROCEDURES}

\section{Materials}

NP1 and NP2 were expressed and purified as previously described (44). S-Nitroso- $N$ acetylb,L-penicillamine (SNAP) was bought from World Precision Instruments. NO gas $(98.5 \%)$, methyl viologen dichloride hydrate, anthraquinone-2-sulfonic acid sodium salt, $\mathrm{Ru}$ $\left(\mathrm{NH}_{3}\right)_{6} \mathrm{Cl}_{3}$, and ferroceneacetic acid were from Sigma-Aldrich. $\mathrm{D}_{2} \mathrm{O}(99.9 \% \mathrm{D})$ and acetic acid- $d_{4}(99.5 \% \mathrm{D})$ were bought from Cambridge Isotope Laboratories, Inc (MA). 


\section{Expression and Purification of wt NP7 and NP7(D1-3)}

The proteins were expressed and reconstituted with the heme cofactor as was previously described (45). The proteins were judged by SDS-PAGE to be $\sim 90 \%$ pure. Proteins were subjected to MALDI-TOF MS to confirm the correct molecular masses including an initial Met-0 residue in both cases and accounting for two Cys-Cys disulfides (calculated for [wt NP7 $+\mathrm{H}]^{+}:$20,969 Da, observed: 20,966 Da; calculated for [NP7 $\left.(\Delta 1-3)+\mathrm{H}\right]^{+}: 20,702 \mathrm{Da}$, observed: $20,698 \mathrm{Da}$ ). Proteins were stored frozen at $-20^{\circ} \mathrm{C}$ in $200 \mathrm{mM} \mathrm{NaOAc} / \mathrm{HOAc}, 10 \%(\mathrm{v} / \mathrm{v})$ glycerol (pH 5.0) until use.

\section{Measurement of Ligand Binding Constants for Fe $\mathrm{Fe}^{\text {III }}$ Complexes of the Nitrophorins}

Association constants were determined by titration experiments at $27 \pm 1{ }^{\circ} \mathrm{C}$ where absorption spectra where recorded between 325 and $800 \mathrm{~nm}$ essentially as described previously (44). In the case of NO titrations, all solutions were purged with Ar and a SNAP solution $(200 \mu \mathrm{M}$ in the presence of $50 \mu \mathrm{M} \mathrm{Na}{ }_{2} \mathrm{EDTA}$ ) was used as the NO source. In order to release NO from SNAP (46), a few crystals of $\mathrm{CuCl}$ were added to the Ar purged buffer solution and filtered. Protein samples were extensively dialyzed (NMWL: $12-14 \mathrm{kDa}$ ) against Ar purged buffer.

\section{Spectroelectrochemical Titrations}

These were carried out using the same instrumentation and the same reference electrode (Ag/ $\mathrm{AgCl}, E^{\circ}=-205 \mathrm{mV} v$ s. SHE) at $27 \pm 1{ }^{\circ} \mathrm{C}$ as described previously $(16,28,44)$. Protein samples were rendered essentially $\mathrm{O}_{2}$ free by dialysis (NMWL: $12-14 \mathrm{kDa}$ ) in Ar purged buffer overnight. Methyl viologen, anthraquinone-2-sulfonic acid, and $\mathrm{Ru}\left(\mathrm{NH}_{3}\right)_{6} \mathrm{Cl}_{3}$ (in the case where no ligand was added or histamine was bound) or anthraquinone-2-sulfonic acid, $\mathrm{Ru}$ $\left(\mathrm{NH}_{3}\right)_{6} \mathrm{Cl}_{3}$, and ferroceneacetic acid (with $\mathrm{NO}$ bound which was added as SNAP) were used as electrochemical mediators at $\sim 200 \mu \mathrm{M}$ concentrations (16,28). Measurements were performed with either no ligand or a high enough concentration of ligand $\mathrm{L}$ to insure full complexation of both oxidation states where SNAP was used as the NO source.

\section{Kinetics of NO Release}

Samples of $w t$ NP7 or NP7( $\Delta 1-3)(\sim 10 \mu \mathrm{M})$ in $100 \mathrm{mM}$ MOPS/NaOH $(\mathrm{pH} 7.5)$ were loaded with a slight excess of sodium $(Z)$-1-( $N, N$-diethylamino)diazen-1-ium-1,2-diolate (DEA/NO). Excess DEA/NO (or its decomposed products) was washed out using a Centricon-10 (Millipore) ultrafiltration device. To observe kinetics, equal volumes of protein-NO complex and $10 \mathrm{mM}$ imidazole $(\operatorname{ImH})$ dissolved in the same buffer as the protein were rapidly mixed using an Olis Stopped-Flow RSM 1000 instrument equipped with a water bath-thermostated cuvette holder which was adjusted to $25 \pm 1^{\circ} \mathrm{C}$. Absorption changes at $423 \mathrm{~nm} v$ s. time were fitted with a single exponential using orIGIN V7.5 software (OriginLab, Inc.). The measurements were repeated a number of times and averaged.

\section{Thermal Stability}

Protein samples of $\sim 5 \mu \mathrm{M}$ in $30 \mathrm{mM} \mathrm{NaH}_{2} \mathrm{PO}_{4} / \mathrm{NaOH}$ (pH 5.5) were filled into a quartz cuvette and placed into a temperature adjustable cuvette holder in a UV-vis spectrophotometer.

Temperatures were adjusted by an external water bath between 20 and $70{ }^{\circ} \mathrm{C}$ in steps of $\sim 5^{\circ}$

C. Temperatures were determined at the cuvette holder and spectra recorded between 300 and $600 \mathrm{~nm}$ after the temperature was stable for $5 \mathrm{~min}$.

\section{EPR Spectroscopy}

Samples for EPR spectroscopy were concentrated in Biomax ultrafiltration concentrators with a NMWL of $10 \mathrm{kDa}$ (Millipore). After the concentration reached $\sim 1 \mathrm{mM}$, buffer was exchanged in the concentrators with $50 \mathrm{mM}$ MOPS/NaOH (pH 7.5). For the preparation of the ferroheme- 
NO complex, NP7 in $100 \mathrm{mM} \mathrm{NaOAc/HOAc}$ (pH 5.0) was first reduced by the addition of 10 $\mathrm{mM} \mathrm{Na} \mathrm{S}_{2} \mathrm{O}_{4}$. The protein was then separated using a $5 \mathrm{~mL}$-HiTrap Desalting column (Amersham Biosciences) in $100 \mathrm{mM} \mathrm{NaOAc/HOAc}(\mathrm{pH}$ 5.0). The protein fraction was briefly subjected to excess NO gas and again separated by the HiTrap Desalting column in $100 \mathrm{mM}$ $\mathrm{NaOAc/HOAc}$ (pH 5.0). EPR spectra were recorded at $4.2 \mathrm{~K}$ on a Bruker ESP-300E EPR spectrometer operating at X-band, using a Systron-Donner frequency counter to measure the microwave frequency. Instrument settings included $0.2 \mathrm{~mW}$ microwave power, $100 \mathrm{kHz}$ field modulation, and a modulation amplitude of $4 \mathrm{G}$.

\section{NMR Spectroscopy}

For the buffered NMR solution exchangeable protons in $\mathrm{Na}_{2} \mathrm{HPO}_{4}$ and $\mathrm{ImH}$ were exchanged against deuterons by three solvation/freeze-dry cycles with $\mathrm{D}_{2} \mathrm{O}$. The $\mathrm{pH}$ was then adjusted through titration with acetic acid- $d_{4}$ using a standard $\mathrm{pH}$ electrode $\left(\mathrm{H}_{2} \mathrm{O}\right)$; therefore, the buffers are not corrected for the deuterium effect (designated $\left.\mathrm{pH}^{*}\right)$.

$W t \mathrm{NP} 7$ and NP7( $\triangle 1-3$ ) in $100 \mathrm{mM} \mathrm{NaOAc/HOAc}$ (pH 5.0) were concentrated using Biomax ultrafiltration concentrators (NMWL: $10 \mathrm{kDa}$ ) (Millipore). Buffer was exchanged through extensive washing (10 times) with $30 \mathrm{mM} \mathrm{Na} 2 \mathrm{DPO} 4 /$ acetic acid- $d_{4}$ in $\mathrm{D}_{2} \mathrm{O}\left(\mathrm{pH}^{*} 5.5\right.$ or 7.0, respectively) in the same ultrafiltration devices. NP1 and NP2 samples were prepared from lyophilisates as has been previously described $(15,23,24,27)$. NMR samples finally consisted of $1-2 \mathrm{mM}$ protein solutions. To obtain the low-spin complexes, protein samples were mixed with excess $\mathrm{ImD} /$ acetic acid- $d_{4}\left(\mathrm{pH}^{*} 5.5\right.$ or 7.0 , respectively; final concentration: $20 \mathrm{mM}$ ) prior to ultrafiltration. NMR data were collected at $25^{\circ} \mathrm{C}$ with the chemical shift referenced to residual water on a Bruker DRX-500 spectrometer operating at 499.58-MHz proton Larmor frequency.

\section{Structural Model of NP7}

Amino acid sequences of $R$. prolixus NP1-4 were aligned with NP7 using the program мuscLE $\mathrm{V} 3.6^{3}$ (47). Based on this alignment a homology model of NP7(G3-S182) was built using the swiss-модеL server ${ }^{4}(48,49)$ and the software DEepviEw V3. $7^{5}(50)$. The following X-ray structures were used as modeling templates: PDB code 1 T68 (NP2-NO), PDB code 1PEE (NP2-ImH), PDB code 1EUO (NP2- $\left.\mathrm{H}_{2} \mathrm{O}\right)(32)$, and $\mathrm{PDB}$ code $2 \mathrm{~A} 3 \mathrm{~F}\left(\mathrm{NP} 2-\mathrm{H}_{2} \mathrm{O}\right)$. Upon superposition of the NP7 model structure with the NP2- $\mathrm{H}_{2} \mathrm{O}$ crystal structure (PDB code $2 \mathrm{~A} 3 \mathrm{~F}$ ) the heme cofactor was manually inserted into the NP7 model and modified to 2,4-dimethyl deuteroporphyrin IX (symmetrical heme). Finally, the structure was manually refined where the Gromos 96 implementation in DEEPVIEw was used for local energy minimization ( 200 cycles of steepest descents followed by 300 cycles of conjugated gradients). The modeling result was evaluated by the wHAт_снеск 6 (51) and РRоснеск software $^{6}(52)$.

\section{Dynamic Light Scattering}

The NMR samples of NP2-ImH ( $\left.2 \mathrm{mM}, \mathrm{pH}^{*} 7.0\right)$ and $w t \mathrm{NP} 7-\operatorname{ImH}\left(\sim 2 \mathrm{mM}, \mathrm{pH}^{*} 5.5\right)$ were aligned in the sample holder of a BI-2030AT Laser Light Scattering Goniometer (Brookhaven Instruments Inc., Holtsville, NY), $90^{\circ}$ to a $5 \mathrm{~mW}$ He/Ne laser (632.8 nm; Melles-Griot Corp., Carlsbad, CA). The relative intensity of the Rayleigh scattering was plotted vs. the logarithm of the apparent hydrodynamic diameter.

\footnotetext{
$3_{\text {http://phylogenomics.berkeley.edu/cgi-bin/muscle/input_muscle.py/. }}$

${ }_{5}^{4} \mathrm{http}: / /$ swissmodel.expasy.org/.

$5 \mathrm{http}: / /$ swissmodel.expasy.org/spdbv/.

$6_{\text {http://swissmodel.expasy.org/workspace/. }}$
} 


\section{RESULTS}

\section{Amino Acid Sequence of NP7}

NP1-4 were previously isolated from the saliva of $R$. prolixus and their N-terminal amino acid sequences were obtained through Edman degradation (7). Comparison with the coding DNA revealed the corresponding signal peptides that are cleaved during the export into the salivary gland lumen (53). NP7, however, was derived solely from a cDNA library and the signal peptide sequence was computed using the software signalP V2.0 (38). From these calculations, NP7 was predicted to contain three additional amino acid residues ${ }^{1}$ Leu-Pro-Gly ${ }^{3}$ at the Nterminus whereas NP1-4 are all cleaved one residue before Cys-2. An amino acid sequence alignment of NP7 with NP1-4 was performed using the muscLE V3.6 web server ${ }^{3}$ and is displayed in Figure 1. In a recent comparative study of three N-terminal forms of NP2, i.e., $\mathrm{Met}^{0}-\mathrm{NP} 2$, NP2(D1A), and ${ }^{-3}$ Gly-Ser-His-Met ${ }^{0}-\mathrm{NP} 2$ (compare Figure 1 and Scheme 1) it was found that even small changes in the $\mathrm{N}$-terminal sequence of $R$. prolixus nitrophorins can have major effects on the protein properties (44).

We revisited the prediction of the signal peptidase cleavage site using the sIGNALP web server, ${ }^{7}$ for which the new version (3.0) was recently released with an improved accuracy (54-56). In parallel, the signal peptides of NP1-4 were also predicted as a benchmark for the accuracy of the method for $R$. prolixus nitrophorins (Table 1). The neuronal network (NN) approach of SIGNALP V3.0 predicted the highest probability with a sufficient $D$-score (55) for the actual sites of NP1-4. For NP1 and NP4 the correct cleavage site was also predicted by the hidden Markov model (HMM) approach; however, for NP2 and NP3 the HMM predicted the maximum probability at different sites (Table 1; Figure 1). Furthermore, the probability for the presence of the cleavage sites was below the threshold of significance $(<0.5)$. However, for NP7 the signal peptide cleavage site calculated previously with signaLP V2.0 (38) could be verified with good scoring by applying both the NN and HMM approaches (Table 1;Figure 1). Overall, SIGNALP V3.0 was able to predict the correct signal peptide cleavage site of $R$. prolixus nitrophorins with reasonable reliability (total $75 \%$ accuracy) for NP1-4 which is close to the proposed accuracy (79.0\% for NN; 75.7\% for HMM) (55). Thus, the prediction of the cleavage site for NP7 by both the NN and HMM approach with rather high scoring in both cases (Table 1) seems reliable but not totally without doubt. In view of the previous results on the differences in Nterminal NP2 variants (44), we decided to characterize NP7 with the first three amino acids (designated $w t$ NP7) and the truncated form (designated NP7( $\Delta 1-3)$ ). The recombinant expression of both proteins was accomplished in good yield in E. coli cells. Like for NP1-3, due to the recombinant expression of nitrophorins in $E$. coli, a Met- 0 residue was added to the amino acid sequence in the case of NP7 and NP7( $\Delta 1-3)$ that results from the translation of the start-codon 5'-ATG-3' (Scheme 1). The presence of the Met-0 was affirmed by mass spectrometry.

\section{Association Constants of NO and Histamine}

Similar to NP1 (13), NP7 released NO at pH 7.5 when Ar was blown over the sample surface while maintaining the oxidation state +3 (45). To compare the affinity of NP7 for NO with those of the other nitrophorins, association constants $K_{\mathrm{eq}}^{\mathrm{III}}$ for NO binding to ferric $w t$ NP7 and $\operatorname{NP7}(\Delta 1-3)$ were determined by titrations at $\mathrm{pH} 5.5$ and 7.5 (44). Figure 2 gives an example of the titration of $w t$ NP7 with NO at pH 7.5, which shows good isosbestic behavior. The resulting values are summarized in Table 2 in comparison to the reported values for NP1-4 and several NP2 mutant proteins relevant to this study $(21,28)$. Like the other $R$. prolixus nitrophorins, $w t$ NP7 binds NO at low pH very tightly and switches to a lower affinity at serum $\mathrm{pH}$. In fact,

\footnotetext{
$7_{\text {http://www.cbs.dtu.dk/services/SignalP/. }}$
} 
in the case of $w t$ NP7 this switch of the association constant is the largest observed among the nitrophorins ( $2-3$ orders of magnitude). This difference is a prerequisite for nitrophorin function. It is, however, the largest difference in $K_{\text {eq }}^{\text {III }}$ between the two $\mathrm{pH}$ values observed for any nitrophorin. In marked contrast, NP7( $\Delta 1-3)$ exhibited the largest $K_{\text {eq }}^{\mathrm{III}}$ at plasma $\mathrm{pH}$, suggesting that this protein would not be capable of releasing NO in blood plasma, while, opposite to the general trend, the $K_{\text {eq }}^{\mathrm{III}}$ at $\mathrm{pH} 5.5$ drops approx. one order of magnitude.

NP1-4 not only aid the insect by NO release, but also by trapping histamine at the open Fe $\mathrm{Fe}^{\mathrm{III}}$ coordination site to suppress the victim's immune response (19). Because the human plasma concentration of histamine is relatively small $\left(1-10 \times 10^{-9} \mathrm{M}\right)(57)$ the $K_{\mathrm{eq}}^{\mathrm{III}}$ of NP1-4 at pH 7.5 are in the range of $\sim 10^{8} \mathrm{M}^{-1}$ (Table 2) in order to trap significant amounts of histamine $(21,28)$. In marked contrast, NP7 exhibits a three orders of magnitude smaller association constant (Table 2), suggesting that this protein is not able to sequester histamine in vivo. To investigate further if the lower histamine affinity is a matter of the specific heme properties of NP7 and/or the NP7 polypeptide chain, $K_{\text {eq }}^{\mathrm{III}}$ was also determined for ImH. It turned out that ImH binds with a similar affinity to $w t$ NP7 $7^{\mathrm{III}}$ as it does to NP1-4 ${ }^{\mathrm{III}}$ (Table 2); therefore, it is concluded that the difference between $\operatorname{ImH}$ and histamine is caused by the additional ethylammonium moiety of histamine. In fact, in the X-ray structures of NP4-Hm at pH 5.6 (PDB code 1IKE) (35) and NP1-Hm at pH 7.5 (PDB code 1NP1) (31), histamine: $\mathrm{NH}_{3}{ }^{+}$was hydrogen bonded to Asp-30: $\mathrm{C}^{\gamma} \mathrm{OO}^{-}$and the backbone $\mathrm{C}=\mathrm{O}$ of Gly-131. In the case of NP1$\mathrm{Hm}$, further hydrogen bonding to the backbone $\mathrm{C}=\mathrm{Os}$ of Glu-32 and Leu-130 occurred. Mutation of Asp-30 in NP4 to Asn or Ala significantly decreased histamine association constants (30). Likewise, mutation of the equivalent residue Asp-29 to Ala in NP2(D1A) also decreased the histamine association constant at $\mathrm{pH} 7.5$ by $10^{2}-10^{3} \mathrm{M}^{-1}$ whereas the $\mathrm{ImH}$ association constants remained nearly unchanged (Berry, Shokhirev, Ho, Zhang, and Walker, to be submitted) (Table 2). Moreover, X-ray crystallography of NP4 showed that those residues involved in histamine: $\mathrm{NH}_{3}{ }^{+}$binding are embedded in a larger hydrogen bonding network in which the $\mathrm{N}$-terminal $\mathrm{C}^{\alpha}-\mathrm{NH}_{3}{ }^{+}$(Ala-1) is strongly involved (30). Consequently, elongation of the $\mathrm{N}$-terminus could have an influence on the histamine binding affinity. This hypothesis is supported by the fact that NP7( $\Delta 1-3)$, in contrast, resulted in an increased $K_{\text {eq }}^{\mathrm{III}}$ comparable to NP1-4 (Table 2), thus indicating that the opening of the heme pocket is indeed influenced by the N-terminus. However, in contrast to NP7, the N-terminal variants of NP2 did not show significant differences regarding histamine binding, which supports the idea that the Nterminus of $w t \mathrm{NP7}$ is somewhat unique in that ability to decrease histamine affinity.

Because of the high affinity of NO for Fe $\mathrm{FI}^{\mathrm{II}}$ centers, $K_{\text {eq }}^{\mathrm{II}}$ is difficult to measure directly. However, the shift of the $\mathrm{Fe} e^{\mathrm{III}} / \mathrm{Fe}^{\mathrm{II}}$ reduction potential when a ligand $\mathrm{L}$ is bound to the iron is a measure of the ratio of the $\mathrm{Fe}-\mathrm{L}$ binding constants for the two oxidation states, since the Nernst equation (equation 2, see below) can be rewritten as:

$$
E_{\mathrm{c}}^{\mathrm{o}}-E^{\mathrm{o}}=\frac{R T}{n F} \ln \frac{K_{\mathrm{eq}}^{\mathrm{III}}(\mathrm{L})}{K_{\mathrm{eq}}^{\mathrm{II}}(\mathrm{L})}
$$

where $E_{\mathrm{c}}^{\mathrm{o}}$ is the measured potential for the nitrophorin fully complexed to the ligand $\mathrm{L}$ in both oxidation states, $E^{\circ}$ is the measured potential for the nitrophorin in the absence of $\mathrm{L}, R$ is the gas constant, $T$ is the temperature, $n$ is the number of electrons involved $(=1), F$ is the Faraday constant, and $K_{\text {eq }}^{\mathrm{III}}(\mathrm{L})$ and $K_{\mathrm{eq}}^{\mathrm{II}}(\mathrm{L})$ are the association constants for ligand $\mathrm{L}$ to the $\mathrm{Fe}^{\mathrm{III}}$ and $\mathrm{Fe}^{\mathrm{II}}$ states, respectively. Thus, the combination of the two reduction potentials $E^{\circ}$ and $E_{\mathrm{c}}^{\mathrm{o}}$ (see next section) together with $K_{\text {eq }}^{\mathrm{III}}(\mathrm{L})$ allowed the calculation of $K_{\mathrm{eq}}^{\mathrm{III}}(\mathrm{L}) \mathrm{s}$, which are reported in 
Table 2 as well. The low histamine affinity of $w t$ NP7 $7^{\mathrm{III}}$ compared to NP7( $\left.\Delta 1-3\right)^{\mathrm{III}}$ and the other ferric nitrophorins is reflected also by an extraordinary low $K_{\text {eq }}^{\mathrm{II}}(\mathrm{Hm})$.

Similarly, the large difference of $K_{\mathrm{eq}}^{\mathrm{III}}(\mathrm{NO})$ of $w t \mathrm{NP7}$ between pH 5.5 and 7.5 is also reflected in the corresponding $K_{\mathrm{eq}}^{\mathrm{II}}(\mathrm{NO})$. Remarkably, the calculated $K_{\text {eq }}^{\mathrm{II}}$ for NP7 $(\Delta 1-3)$ reflect not only the lowest $\mathrm{NO}$ affinity at $\mathrm{pH} 5.5$, but also the highest $\mathrm{NO}$ affinity at $\mathrm{pH} 7.5$ among all NPII species reported, indicating that other factors besides the iron oxidation state strongly influence the Fe ${ }^{\mathrm{II}}-\mathrm{NO}$ bond.

\section{Spectroeletrochemical Titrations}

Spectroelectrochemical titrations of NP7 and NP7( $\Delta 1-3)$ were performed at low and high pH with $\mathrm{H}_{2} \mathrm{O}, \mathrm{NO}$, and histamine as ligands (Table 3). Figure 3 shows the measurement of reduction potential of $w t \mathrm{NP7}-\mathrm{Hm}$ at $\mathrm{pH} 7.5$ as an example. The reduction potentials $E^{\circ}$ were derived from the fitting of the spectroscopic change at a single wavelength according to the Nernst equation

$$
E_{\text {app }}^{\mathrm{o}}=E^{\mathrm{o}}+2.303 \frac{R T}{n F} \log _{10} \frac{\left[\mathrm{NP}^{\mathrm{III}}\right]}{\left[\mathrm{NP}^{\mathrm{II}}\right]}
$$

where $E_{\text {app }}^{\mathrm{o}}$ is the applied potential and $[\mathrm{NP} \mathrm{III}]$ and $\left[\mathrm{NP}^{\mathrm{II}}\right]$ are the equilibrium concentrations of ferric and ferrous NP, respectively, which can be determined from the absorption spectra at each applied potential by using Beer's law. The resulting values are summarized and compared to NP1-4 in Table 3. Overall, the values obtained for $w t$ NP7 are generally higher, but still close to the other isoforms. However, NP7- $\mathrm{H}_{2} \mathrm{O}$ and NP7-Hm exhibit the highest $E^{\circ}$ at both $\mathrm{pH}$ values and are only topped by NP1-NO complexes (by $+60 \mathrm{mV}$ at $\mathrm{pH} 5.5$ and $+18 \mathrm{mV}$ at $\mathrm{pH}$ 7.5). Thus, the Fe $\mathrm{III}^{\mathrm{II}}$ oxidation state tends to be less stabilized in NP7 compared to NP1-4.

The picture is more dramatic for NP7( $\Delta 1-3)$ where all reduction potentials were found to be positively shifted on average $+85 \mathrm{mV}$ as compared to the $w t$ (Table 3 ). This is an unprecedented shift resulting from a seemingly mild modification. For comparison, ${ }^{-3} \mathrm{Gly}-\mathrm{Ser}-\mathrm{His}-\mathrm{Met}^{0}{ }_{-}$ NP2 exhibited only a marginal ( $+23 \mathrm{mV}$ ) change compared to $w t$ NP2 (44). This again points to an important role of the N-terminal sequence of NP7 for its functionality.

Whereas the reduction of NP7-NO at $\mathrm{pH} 7.5$ resulted in a slight shift of the Soret band from $414 \mathrm{~nm}\left(\mathrm{NP7} 7^{\mathrm{III}}-\mathrm{NO}\right)$ to between $411 \mathrm{~nm}\left(\mathrm{NP}^{\mathrm{II}}-\mathrm{NO}\right)$ and, reduction of NP7-NO at pH 5.5 in the spectroelectrochemical cell resulted in a broad Soret band maximum at $\sim 380 \mathrm{~nm}$ (Figure 4A), which is indicative of a switch to a 5-coordinate (protein ligand off) nitrosyl complex, and upon reoxidation, the Soret maximum was restored to the initial $419 \mathrm{~nm}$, i.e., the 6coordinate $\mathrm{Fe}^{\mathrm{III}}-\mathrm{NO}$ was re-formed. To prove that indeed a 5-coordinate $\mathrm{Fe}^{\mathrm{II}}-\mathrm{NO}$ species was formed at low $\mathrm{pH}$, the EPR spectrum of a sample of NP7-NO reduced with $\mathrm{Na}_{2} \mathrm{~S}_{2} \mathrm{O}_{4}$ at $\mathrm{pH}$ 5.0 was recorded (Figure 4B). The resulting spectrum with $g_{\text {iso }}=2.01$ and the ${ }^{14} \mathrm{~N}$ hyperfine splitting $(I=1)$ is typical for a 5-coordinate ferroheme nitrosyl (58-60). In contrast to $w t$ NP7, $\mathrm{NP} 7(\Delta 1-3)$ showed the formation of a 5 -coordiante $\mathrm{Fe}^{\mathrm{II}}-\mathrm{NO}$ species upon reduction at $\mathrm{pH} 7.5$ (Figure 4C), but not at $\mathrm{pH}$ 5.5. This reverse $\mathrm{pH}$ behavior has not previously been observed for any other $R$. prolixus nitrophorin.

\section{Kinetics of NO Release}

The reaction between ferric nitrophorins and $\mathrm{NO}$ can be described by the equilibrium reaction depicted in Scheme 2. The reaction is described by the simple equation

$$
k_{\mathrm{obs}}=k_{\mathrm{on}} \times[\mathrm{NO}]+k_{\mathrm{off}}
$$


where [NO] is the $\mathrm{NO}$ concentration, $k_{\mathrm{off}}$ is the reverse rate constant (or dissociation constant) and $k_{\text {on }}$ the second order rate constant for NO binding. Both $k_{\text {off }}$ and $k_{\text {on }}$ can be determined from the association reaction by measuring $k_{\mathrm{obs}}$ at various $\mathrm{NO}$ concentrations. However, $k_{\mathrm{off}}$ determined by this experiment for systems with very large association constants $K_{\mathrm{eq}}=k_{\mathrm{on}}$ I $k_{\text {off }}$ are unreliable, and the reverse rate constant obtained represents the dissociation of NO from the unstabilized pre-equilibrated $\mathrm{Fe}^{\mathrm{III}}-\mathrm{NO}$ complex (28). Rather, the dissociation rate constant $\left(k_{\text {off }}\right)$ for the release of $\mathrm{NO}$ from the equilibrated Fe ${ }^{\mathrm{III}}-\mathrm{NO}$ complex was determined independently by measuring the rate of the displacement reaction by $\mathrm{ImH}$ according to Scheme 3. For this purpose, $w t \mathrm{NP7}$ or NP7 $(\Delta 1-3)(\sim 10 \mu \mathrm{M})$ were loaded with NO as described in the experimental section and then rapidly mixed in a quartz cuvette with an equal volume of buffer containing $10 \mathrm{mM} \mathrm{ImH}$. The displacement reaction was followed at $423 \mathrm{~nm}$ using a stoppedflow spectrophotometer for which a representative experiment is shown in Figure 5. The displacement reaction shown in Scheme 3 can be described by the following equation

$$
k_{\mathrm{obs}}=\frac{k_{\mathrm{off}}}{1+\frac{k_{\mathrm{on}} \times[\mathrm{NO}]}{k^{\mathrm{mH}} \times[\mathrm{ImH}]}}
$$

where $k_{\mathrm{obs}}$ is the observed first order displacement rate constant, $k_{\mathrm{off}}$ is the NO dissociation rate constant, $k_{\mathrm{on}}$ is the bimolecular rate constant for $\mathrm{NO}$ binding, [ImH] is the imidazole concentration, $k^{\mathrm{ImH}}$ is the bimolecular rate constant for $\operatorname{ImH}$ binding, and [NO] is the NO concentration. In this NO displacement experiment, $[\mathrm{NO}]<<[\mathrm{ImH}]$. Thus the rate of NO association is insignificant, and NO displacement is rate-determining. Under these conditions equation 4 simplifies to $k_{\text {obs }}=k_{\text {off }}$. The resulting absorption traces were fit with a single exponential that resulted in a good fit for both proteins (as shown by the residuals in Figure 5 for $w t$ NP7). The average $k_{\text {off }}$ from a number of repeated experiments are given in Table 4 together with the corresponding $k_{\text {on }}$ values which were calculated from the association constants given in Table $2\left(K_{\mathrm{eq}}=k_{\mathrm{on}} / k_{\mathrm{off}}\right)$.

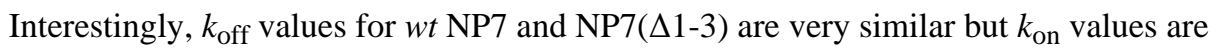
significantly different from each other as a consequence of very different $K_{\mathrm{eq}}$ values. In comparison to NP1-4 (28) (Table 4), the $k_{\text {off }}$ decreases in the order NP1/4 > NP7 > NP2/3. The $k_{\text {on }}$ for $w t$ NP7 appears very similar to NP1/4, but the very fast $k_{\text {on }}$ for NP7( $\left.\Delta 1-3\right)$ is very different from any of the other nitrophorin values; thus, the ${ }^{0} \mathrm{Met}-\mathrm{Leu}-\mathrm{Pro}-\mathrm{Gly}^{3} \mathrm{~N}$-terminus strongly contributes to $k_{\text {on }}$ rather than $k_{\text {off. It }}$ should be noted that biphasic reaction kinetics were reported for NP1/4 and for NP2/3 to a lesser extent (28), but in this work only one phase could be observed for NP7. The two different rates for NP1/4 have been attributed to the two different heme $b$ orientation isomers (44) and since NP7 is dominated by the A heme orientation (see below) it is not surprising that the amplitude due to a second, slow phase is too small to observe. Therefore, in this study only the fast phase, which is the major fraction of the reaction, was used for comparisons.

\section{Protein Stability}

To study the influence of the N-terminus on the stability of NP7, the temperature dependence on the fold stabilization of $w t$ NP7 and NP7( $\Delta 1-3)$ was studied. Increasing light scattering at temperatures $\geq 60{ }^{\circ} \mathrm{C}$ (for $w t \mathrm{NP} 7$ ) and $\geq 55^{\circ} \mathrm{C}$ (for NP7( $\left.\Delta 1-3\right)$ ) indicated protein aggregation, which did not allow refolding. The Soret absorbance at $411 \mathrm{~nm}$ was plotted $v s$. temperature for both proteins upon subtraction of the absorbance at $600 \mathrm{~nm}$ which partly accounted for the increased light scattering at higher temperature (Figure 6). The Soret absorbance constantly decreased with increasing temperature in the case of NP7( $\Delta 1-3)$ until at $\sim 45^{\circ} \mathrm{C}$ a marked absorbance decay occurred accompanied by Soret band broadening and shift of the maximum to shorter wavelength. Wt NP7, in contrast, was comparatively stable, and did not experience a marked signal decrease before $>52{ }^{\circ} \mathrm{C}$. Thus, it can be concluded that the N-terminus of NP7 significantly stabilizes the protein fold. 
Attempts to observe the difference in fold stabilization free energy $\Delta G_{\mathrm{f}}^{0}$ were made by using guanidinium chloride titration experiments, as have been performed in the case of other heme $b$ proteins such as horse heart $\mathrm{Mb}(61)$ and cytochrome $b_{562}(62)$. However, due to the irreversibility of the process at both $\mathrm{pH} 7.0$ and 5.0 proper data analysis was not possible.

\section{Homology Model of NP7}

To examine the structural properties of the heme cavity as well as to attempt to rationalize the strong influence of the N-terminus a homology model of NP7 was built. The amino acid sequence of NP7 is $61 \%$ identical to NP2 without any gap in the sequence alignment (Figure 1). This allowed the calculation of a reliable homology model of NP7(G3-S182), which was based on the crystal structures of ferric NP2- $\mathrm{H}_{2} \mathrm{O}, \mathrm{NP} 2-\mathrm{NO}$, and NP2-ImH. Because of the asymmetry of the heme $b$ cofactor it can be inserted in two different orientations $\mathbf{A}$ and $\mathbf{B}$ into a protein's heme binding pocket. In the protohemin IX drawings of Scheme 4 the $\mathbf{A}$ isomer is defined as having pyrrole ring II (including $4 \mathrm{~V}$ ) lying above the protein backbone $\mathrm{C}(\mathrm{O}) \mathrm{CN}(\mathrm{H})$ atoms of His-57 (NP2), His-59 (NP1, NP4), or His-60 (NP7) with that His ligand lying behind the plane of the heme in the pictures shown in Scheme 4. For the insertion of the heme $b$ from the NP2- $\mathrm{H}_{2} \mathrm{O}$ crystal structure into the NP7(G3-S182) model structure the cofactor was inserted manually and modified into 2,4-dimethyl deuteroporphyrin IX (symmetrical heme) to allow heme seating to be independent of the placement of the vinyl- $\beta$ carbons that account for the heme $\mathbf{B}$ orientation in the NP2 structure in contrast to the preferential heme $\mathbf{A}$ orientation found in NP7 (see below). The NP7(G3-S182) model structure had an RMSD of $0.39 \AA$ compared to NP2- $\mathrm{H}_{2} \mathrm{O}$ (based on the superposition of 720 atoms) and showed the same lipocalin type of fold (globular; diameter: $\sim 40 \AA$ ) as the other $R$. prolixus NPs, as shown in Figure 7A (Ramachandran plot: favored, $87.7 \%$; allowed, $12.3 \%$; generally allowed, $0.0 \%$; disallowed, $0.0 \%)$.

In the previous report on NP7, a homology model was presented that showed the highly positively charged site opposite the heme pocket due to spatial clustering of a large number of Lys, and that this site accounts for the recognition of negatively charged membrane surfaces (38). Because we noticed the large influence of the N-terminus on the NP7 functionality we were interested in the charge distribution of the surface of the heme entrance site that is close to the $\mathrm{N}$-terminus. The surface representation of the electrostatic potentials of the heme-pocket site of NP7(G3-S182) in comparison to NP2 is displayed in Figure 7B. It shows that the hemepocket site is mostly negatively charged but, unlike for the site opposite of the heme entrance (38), no significant surface-charge differences between the two structures were noticed in the area of the $\mathrm{N}$-terminus.

\section{Magnetic Resonance Spectroscopy}

The NP7 ${ }^{\mathrm{III}}-\mathrm{ImH}$ and NP7( $\left.\Delta 1-3\right)^{\mathrm{III}}-\mathrm{ImH}$ complexes at $\mathrm{pH} 7.5$ showed typical rhombic EPR spectra with values of $g_{\mathrm{x}, \mathrm{y}, \mathrm{z}}=1.36,2.19,3.07$ and $1.38,2.18,3.08$, respectively, which are comparable to NP2 $2^{\mathrm{III}}-\operatorname{ImH}(1.37,2.26,3.02)(15)$ and NP4 4 III-ImH $(1.46,2.25,3.02)(21)$. The comparison of the crystal structures with the EPR spectra of bis(ligand) ferriporphyrin model compounds, e.g., paral-[Fe(octamethyltetraphenylporphyrin)(1-methylimidazole $\left.)_{2}\right] \mathrm{Cl}$, revealed that such a normal rhombic spectrum is indicative of an approximately parallel axial ligand orientation (i.e., His-60 : $\operatorname{ImH})(15,63)$.

The ${ }^{1} \mathrm{H}$ hyperfine-shifted resonances of the ImH complex of $w t$ NP7 and NP7( $\left.\Delta 1-3\right)$ in comparison to NP2 in buffered $\mathrm{D}_{2} \mathrm{O}$ is shown in Figure 8. Reasonably sharp resonances for NP7 could only be obtained at low $\mathrm{pH}$. However, the heme resonances of the other nitrophorins have much smaller average linewidths $\Delta v$ (23). Figure 8 shows as an example the spectra of NP2-ImH at high and low $\mathrm{pH}$, i.e., $\Delta v=89 \mathrm{~Hz}$ at $\mathrm{pH} 7.0$ and $96 \mathrm{~Hz}$ at $\mathrm{pH} 5.5$, whereas for $w t \mathrm{NP7} \Delta v=282 \mathrm{~Hz}$ and NP7( $\Delta 1-3) \Delta v=179 \mathrm{~Hz}$. The number of heme resonances indicates 
that, unlike many other non-covalently bound heme $b$ containing proteins such as cytochromes $b_{5}(64,65)$, one oentation of the unsymmetrical heme group is strongly favored. This result is consistent with the other $R$. prolixus nitrophorins where equilibrium was reached between the $\mathbf{A}$ and $\mathbf{B}$ orientations of the heme $b$, e.g., for NP1-ImH after $12 \mathrm{~h}$ (16). The heme resonances of NP1-ImH and NP2-ImH at pH 7.0 were previously fully assigned (23) and part of the assignments is given in Figure 8. Recording the spectra of NP2-ImH at pH 5.5 obviously yielded moderate shifts of some of the resonances, but the relative position of the signals remained similar, allowing the conclusion that the influence of the $\mathrm{pH}$ on the $\mathrm{ImH}$ and proximal His-57 orientation in NP2 may only be minor (Yang and Walker, to be submitted). However, the appearance of small resonances at lower shielding was noticed; these may be due to reorientation of heme in the pocket to increase the amount of isomer $\mathbf{A}$ as compared to $\mathbf{B}$ and/ or another ImH plane orientation of isomer $\mathbf{B}$. Based on our previous studies of NP2 (24), NP1 and NP4 (22,23), and NP3 (27), we know that the $\mathbf{B}$ isomer is either equal in abundance to, or much more abundant than the $\mathbf{A}$ isomer in all cases (Scheme 4).

The ${ }^{1} \mathrm{H}$ NMR spectra of $w t$ NP7-ImH and NP7( $\left.\Delta 1-3\right)-\operatorname{ImH}$ are very similar to each other, which indicates a very similar chemical environment for the hemes in the two proteins, and minimal effect of the $\mathrm{N}$-terminal sequence on the shape of the heme binding pocket. The small differences between the spectra of $w t$ NP7-ImH and NP7( $\Delta 1-3)-\operatorname{ImH}$ are surprising considering the strong influences of the $\mathrm{N}$-terminal sequence on the protein functionality that we are reporting. However, in comparison to the other nitrophorins, the spectra of both are very different. The shift to lower shielding is the largest observed for any of the nitrophorinImH complexes $(23,24,27)$. To the present, it has not been possible to obtain the assignment of the resonances by COSY and NOESY techniques, mostly due to the very short spin-spin relaxation times, $T_{2}$, that result in large linewidths, as well as loss of magnetization before it can be acquired. Unusually severe line broadening also appeared in the high-spin spectra (data not shown) in comparison to NP1-4 (22). The decreased $T_{2}$ may be a result of charge $\leftrightarrow$ charge interactions between individual NP7 molecules. As was pointed out above, it was previously reported that the surface opposite to the opening of the heme pocket, unlike the other nitrophorins, is highly positively charged (38). In addition, Figure 7B shows that the heme pocket entrance is, like the other nitrophorins, negatively charged, thus making NP7 a charge dipolar molecule. Interactions between NP7 molecules may lead to the transient formation of larger aggregates of various sizes which tumble more or less rapidly in the NMR sample solution and, thus, result in the decreased $T_{2}$ or spin-spin relaxation times. This hypothesis was supported by dynamic light scattering experiments where $w t$ NP7 (apparent hydrodynamic diameter: $\sim 40 \AA$ ) contained a large fraction of oligomers (apparent hydrodynamic diameter: $\sim 250$ - $400 \AA$ ) whereas NP2 was essentially free of oligomers (Figure 9).

However, the integrals of the two resonances at 29.3 and $21.2 \mathrm{ppm}$ (29.7 and $22.1 \mathrm{ppm}$ for NP7 $(\Delta 1-3))$ in comparison to the resonances at $18.3,15.1,13.4,13.0$, and $12.5 \mathrm{ppm}(18.3,15.2$, 13.2 , and $12.6 \mathrm{ppm}$ for $\mathrm{NP7}(\Delta 1-3)$ ) suggest they originate from heme methyl groups, whereas the latter, in comparison to ${ }^{1} \mathrm{H}$ NMR spectra of the other nitrophorin-ImH complexes, are likely $\mathrm{C}^{\alpha} \mathrm{H}_{1 / 2}$ of the vinyl and/or propionate groups (Scheme 4). Usually, the A orientation of the cofactor results in a large shift of the 3-methyl resonance to lower shielding, with that of NP1$\mathrm{ImH}$ and NP4-ImH appearing at 25.1 and $25.7 \mathrm{ppm}$, respectively, at $\mathrm{pH} 7.0$ and $30^{\circ} \mathrm{C}$ (compared to 17.0 and $16.4 \mathrm{ppm}$, respectively, for the $\mathbf{B}$ orientation (23); see Scheme 4). The spectrum of NP1-ImH at $\mathrm{pH}^{*} 7.0$, which exhibits an $\mathbf{A}: \mathbf{B}$ ratio of $\sim 1.1: 1$, is included in Figure 8 (from (23)), where it can be seen that the 3-methyl resonance of isomer $\mathbf{A}$ is found at $25 \mathrm{ppm}$, while NP7 shows its lowest-shielding methyl resonance at $\sim 29 \mathrm{ppm}$. If this is the 3-methyl resonance, then the spectra obtained for NP7-ImH are indicative of the A orientation, and the $\mathbf{B}$ orientation is not observed. Although the latter may be due to the line broadening, in all other nitrophorins, the $\mathbf{A}$ orientation has always been found to be of lesser or similar abundance to B $(22-24,27)$. This is consistent with the spectra recorded for the high-spin species NP7- $\mathrm{H}_{2} \mathrm{O}$ 
(data not shown) where chemical shifts, although being very broad, in comparison to NP1-4$\mathrm{H}_{2} \mathrm{O}$ are indicative of the A orientation. Thus, NP7 appears to be the first nitrophorin that strongly favors the $\mathbf{A}$ heme orientation. Further assignments of the NMR signals will be presented elsewhere.

\section{DISCUSSION}

The reason why the 'kissing bug', R. prolixus, pumps a set of seven nitrophorins into its victim's tissues during various life stages still remains a mystery. Moreover, during the six life stages of the insect that all feed on blood, different expression patterns of NP1-6 have been observed (8). NP7 has been missed in the isolation from salivary glands, probably because of the use of isoelectric focusing chromatography over the $\mathrm{pH}$ range $8.3-7.0$, which is $\sim 1 \mathrm{pH}$ unit below the $\mathrm{pI}$ of apo-NP7 (pI = 9.21, Figure 1). NP7 was later found in a cDNA library derived from $\mathrm{V}^{\text {th }}$ instar nymphs; thus, it is not clear whether the protein is expressed in any of the other developmental stages. NP7 has the ability to inhibit prothrombinase activity through interaction with the prothrombinase activating $\mathrm{L}_{\mathrm{L}} \alpha$-phosphatidyl-L-serine (PS). The binding to PS is accomplished through charge $\leftrightarrow$ charge interactions with the positively charged NP7 surface on the site opposite to the heme entrance site, a fact that contributes mainly to the high pI value $(39,45)$. This function is unique among the $R$. prolixus nitrophorins. It may be noted, however, that NP2 can also inhibit the intrinsic Factor $X$ activating complex, through binding with Factors IX and IX $\mathrm{X}_{\mathrm{a}}$, which represents a third functionality of this protein besides NO delivery and histamine sequestration (32).

Nitrophorins are expressed in the endothelial cells of the salivary glands, and they are secreted into the extracellular space (10); thus their as-expressed amino acid sequences are preceded by an N-terminal leader sequence (Figure 1). The software signalp has been developed to predict the precise site of cleavage for the signal peptidase which was applied in the preceding study, and which proposed that the signal peptide should be cleaved 3 amino acids before the sites known for NP1-6 (38). The application of the novel, more accurate sIGNaLP version 3.0 on the sequence of NP7 led to the same NP7 cleavage site as that previously published (Table 1). To rate the precision of the program for the prediction of native nitrophorin sequences it was applied to NP1-4 amino acid sequences showing that an uncertainty remains. Thus, an NP7 construct, NP7( $\Delta 1-3)$, lacking the ${ }^{0}$ Met-Leu-Pro-Gly ${ }^{3}$ sequence was examined parallel to wt NP7 (Scheme 1).

Comparison of the results for both constructs clearly shows that NP7 needs its isoform-specific $\mathrm{N}$-terminus for proper protein function. In particular, the higher thermostability of wt NP7 shows that the peptide interacts in a specific way with the rest of the polypeptide chain. Also, reduction potentials of $w t \mathrm{NP} 7$ were found to be within a reasonable range compared to the other nitrophorins (Table 3 ) whereas NP7( $\Delta 1-3)$ has markedly more positive reduction potentials which may make it susceptible to reduction and, as a consequence, NO release could not be accomplished. On the other hand, the very similar EPR and ${ }^{1} \mathrm{H}$ NMR spectra of the ImH complexes (Figure 7) suggest that the electronic structureof the heme iron, i.e., the heme orientation, the $\mathrm{ImH}$ plane orientation, and the degree of macrocycle ruffling, are nearly identical. Also, a mixed heme orientation could not be seen, and comparison with the NMR data from NP1-4 suggest a favored A orientation (Scheme 4) in contrast to the otherwise favored $\mathbf{B}$ orientation $(22,23,27)$. A single heme orientation is also supported by the fact that no biphasic kinetics of the NO association/dissociation (Scheme 2) could be observed, which was recently ascribed to the presence of mixed A:B isomers with different rate constants (44). However, as was pointed out in the Results section, in particular the differences in the histamine association constants in particular, but not in the association constants of $\mathrm{ImH}$ (Table 2), indicate differences in the protein structure at the opening of the heme pocket. 
Because Cys-5 in NP7 forms a disulfide bond with Cys-124 the N-terminus is highly constrained and therefore the relative position of the two residues Leu- 1 and Pro- 2 of $w t$ NP7 can be estimated to good approximation in the homology model of NP7(G3-S182) (Figure 7). As was mentioned above, the N-terminus of NP4 was found to be involved in the closed loop structure of the A-B and G-H loops which were recognized to be of major importance for the NP4 histamine and NO binding kinetics (30). Therefore, a closer inspection of the NP7(G3S182) model structure in comparison to the NP2 crystal structure was conducted (Figure 10). The structure in combination with the sequence alignment (Figure 1) shows that the A-B loops are almost identical, with the slight difference of Val-34 in NP2 being represented by Ala-37 in NP7 (see Figure 10). However, the much shorter G-H loop, which begins in all the other NPs with the motif ${ }^{125 / 126} \mathrm{Gly}-(\mathrm{Gln} / \mathrm{Pro} / \mathrm{Ser})-\mathrm{Lys}-\mathrm{Asp}-\mathrm{Leu}{ }^{129 / 130}$, is predicted to be represented by ${ }^{128} \mathrm{Asp}-\mathrm{Gly}-\mathrm{Lys}-\mathrm{Asp}-\mathrm{Ile}{ }^{132}$ in NP7 (Figure 1). As a consequence, the formation of a salt bridge between Asp-128 and Lys-130 (Asp: $\mathrm{O}^{\gamma} \leftrightarrow$ Lys: $\mathrm{N}^{\zeta}=2.9 \AA$; Figure $10)$ is expected, which would increase the rigidity of the G-H loop. This may account for the different properties of NP7( $\Delta 1-3)$ as compared to NP1-4. On the other hand, the ${ }^{1}$ Leu-Pro$\mathrm{Gly}^{3}$ tail of $w t \mathrm{NP7}$ is rather hydrophobic and will be repelled by the mostly polar A-B and G$\mathrm{H}$ loops. However, the hydrophobic site of Ile-132 could interact with the ${ }^{1}$ Leu-Pro-Gly ${ }^{3}$ peptide. In agreement with this hypothesis, the corresponding Leu-130 has been shown to have a major impact on the binding kinetics of NP4 (30).

Due to the recombinant expression of nitrophorins in E. coli, a Met-0 residue is added in the cases of NP1-3 that results from the translation of the start-codon 5'-ATG-3' (Scheme 1) (44). In contrast, NP4 was found to have the starting Met- 0 cleaved off during expression in $E$. coli due to its unique Ala-1 (34). Mutation of NP2 Asp-1 to Ala likewise resulted in the hydrolysis of Met- 0 (Scheme 1) and resulted in a construct with a native $\mathrm{N}$-terminus length. Studies of both constructs together with an NP2 construct that includes a 4-residue addition ${ }^{8}{ }^{-3}$ Gly-Ser-His-Met ${ }^{0}-\mathrm{NP} 2$ (Scheme 1 ) revealed a difference in ${ }^{1} \mathrm{H}$ NMR chemical shifts for heme resonances and significantly slowed kinetics for ligand binding and the equilibration of the $\mathbf{A}: \mathbf{B}$ ratio of the heme orientation (44). This was consistent with the crystal structure of the NP2(D1A) construct (PDB code 2EU7), which shows a significantly more 'closed loop' structure relative to the extended $\mathrm{N}$-terminus constructs. However, the difference in reduction potentials and association constants between $\mathrm{Met}^{0}-\mathrm{NP} 2$ and NP2(D1A) were rather small, suggesting that the Met-0 added to recombinant $w t$ NP7 and NP7( $\Delta 1-3)$ cannot account totally for the large differences between the two constructs reported in this study (Tables 2 and 3). Furthermore, wt NP7 shows significant thermodynamic changes compared to the truncated form NP7( $\Delta 1-3)$. This highlights the important role that the $\mathrm{N}$-terminus plays in the native form of all the NPs.

Similar to NP7, a shift in the absorbance maximum of the Soret band to $395 \mathrm{~nm}$ upon reduction of the NO complex at $\mathrm{pH} 5.5$ was observed and already mentioned for $\mathrm{NP}^{\mathrm{II}}$ and $\mathrm{NP} 3^{\mathrm{II}}$, in contrast to NP1 $1^{\mathrm{II}}$ and $\mathrm{NP} 4{ }^{\mathrm{II}}$ (28). NP1 $1^{\mathrm{II}}-\mathrm{NO}$ was noticed to be at least in part 5-coordinate at low temperature based on EPR spectra at $4.2 \mathrm{~K}$ (16), indicating that labilization of the His: $\mathrm{N}^{\varepsilon}-\mathrm{Fe}^{\mathrm{II}}$ bond occurred due to the strong trans effect of the distal pocket NO ligand, as reported for a number of other heme proteins (17). However, the fact that the His: $\mathrm{N}^{\varepsilon}-\mathrm{Fe}^{\mathrm{II}}$ bond of nitrophorins is only broken at low $\mathrm{pH}$ suggests that the 100 -fold increased $\left[\mathrm{H}^{+}\right]$, and thus imidazolium formation, contributes significantly to the appearance of the 5-coordinate species according to Scheme 5 .

In this context, the appearance of the 5-coordinate species in the case of NP7 $(\Delta 1-3)^{\mathrm{II}}-\mathrm{NO}$ at $\mathrm{pH} 7.5$ rather than $\mathrm{pH} 5.5$ is remarkable. As can be derived from Table 3, when the $\mathrm{pH}$ is raised

\footnotetext{
${ }^{8}$ The NP2 form ${ }^{-3}$ Gly-Ser-His-Met ${ }^{0}-\mathrm{NP} 2$ was obtained from the expression as an N-terminally His6-tagged construct upon thrombin cleavage.
} 
from 5.5 to 7.5 the reduction potentials of all NP1-4-NO complexes decrease by between -27 $\mathrm{mV}(\mathrm{NP} 1-\mathrm{NO})$ and $-41 \mathrm{mV}$ (NP2-NO; in the case of NP2(D1A)-NO even $-68 \mathrm{mV})$. Instead, in the case of $w t \mathrm{NP} 7-\mathrm{NO}$ a slight increase of $+15 \mathrm{mV}$ was measured. However, in the case of $\mathrm{NP7}(\Delta 1-3)-\mathrm{NO}$ a marked increase of $+71 \mathrm{mV}$ occurred at $\mathrm{pH} 7.5$, which indicates a major change in the heme binding pocket. Concomitantly, the reduction potential of NP7( $\Delta 1-3)-\mathrm{NO}$ of $+228 \mathrm{mV}$ at $\mathrm{pH} 7.5$ is unusually high.

While $R$. prolixus NP2, 3, and 7 and many other His-ligated heme proteins form a 5-coordinate $\mathrm{Fe}^{\mathrm{II}}-\mathrm{NO}$ complex only at fairly low $\mathrm{pH}($ e.g., cytochrome $c$ at $\mathrm{pH} 2.0(66))$, there are a few examples of proteins that break the His:N-Fe $\mathrm{II}^{\mathrm{II}}$ bond even at around neutral $\mathrm{pH}$. Examples are the cytochromes $c^{\prime}$ from various species (67-69). A very prominent, but still little understood example of a mono-His heme protein, which looses the His ligand upon NO binding, is the NO sensor soluble guanylate cyclase (sGC) $(70,71)$. In this case, the NO-induced release of the proximal His triggers the activation of the catalytic center of sGC to form cGMP from GTP, which is used as a central second messenger in physiology. However, although this process is well-established, the exact molecular mechanism is still a matter of debate. Unlike NP7, sGC is a cytosolic protein and, consequently, exists in the $\mathrm{Fe}^{\mathrm{II}}$ form, whereas the low reduction potential of the NP7-NO complex suggests that NP7 maintains the Fe ${ }^{\mathrm{III}}$ form to keep its functionality. The +2 oxidation state of sGC is very sensitive to air oxidation, and this causes the problem of losing heme upon oxidation (72). We have been unable to find the exact reduction potential of sGC in the literature, but it can be assumed that it is rather low, since a very mild oxidant such as methylene blue $\left(E^{\circ}=+11 \mathrm{mV}\right.$ at $\left.\mathrm{pH} 7(73)\right)$ readily oxidized the heme iron (74). Besides sGC, there are not many examples of proteins that release their proximal ligand upon NO binding. Human serum albumin (HSA) and the proximal His deletion mutant $\mathrm{H} 93 \mathrm{G}$ of sperm whale $\mathrm{Mb}(\mathrm{Mb}(\mathrm{H} 93 \mathrm{G})$ ) complexed to $\mathrm{ImH}$ have been used as models (75). The NP7( $\Delta 1-3)$ mutant, however, provides a novel model system to study the process that leads to 5-coordination since it is independent of $\left[\mathrm{H}^{+}\right]$. Future studies along these lines are planned.

\section{CONCLUSIONS}

Our study shows that NP7 is a protein-based NO-donor system as are NP1-4. However, NP7 has some remarkable functional differences which include $(i)$ the largest difference in NO association constants between high and low $\mathrm{pH}$, (ii) a small histamine affinity, suggesting that it will not contribute to histamine sequestration in vivo, (iii) large ${ }^{1} \mathrm{H}$ NMR chemical shifts for the $\mathrm{Fe}^{\mathrm{III}}$ form of the protein, and (iv) strong favoring of the $\mathbf{A}$ orientation of the heme. Most of all, a unique N-terminal peptide ${ }^{1}$ Leu-Pro-Gly ${ }^{3}$ is present, which contributes significantly to the protein fold stability. Moreover, the N-terminus is very important to maintaining NP7 function.

\section{Supplementary Material}

Refer to Web version on PubMed Central for supplementary material.

\section{Acknowledgment}

The authors are grateful to Dr. Tatiana Kh. Shokhireva for helpful discussions, to Dr. Andrei V. Astashkin for recording the EPR spectra, and to Mr. David Roberts and Dr. Craig A. Aspinwall for help with the dynamic light scattering experiments (all Department of Chemistry, University of Arizona).

\section{REFERENCES}

1. Walker, FA.; Montfort, WR. Advances in Inorganic Chemistry. Mauk, AG.; Sykes, AG., editors. 51. Academic Press; San Diego (United States): 2001. p. 295-358. 
2. Lehane, MJ. The Biology of Blood-Sucking in Insects. 2 ed.. Cambridge University Press; Cambridge (United Kingdom): 2005.

3. Zeledón R, Rabinovich JE. Chagas' disease: An ecological appraisal with special emphasis on its insect vectors. Annu. Rev. Entomol 1981;26:101-133. [PubMed: 6791582]

4. Kirchhoff LV. American trypanosomiasis (Chagas' disease) - A tropical disease now in the United States. N. Engl. J. Med 1993;329:639-644. [PubMed: 8341339]

5. Wood SF. Observations on vectors of Chagas' disease in the United States. I. California. Bull. Calif. Acad. Sci 1942;41:61-69.

6. Ribeiro JMC, Francischetti IMB. Role of arthropode saliva in blood feeding: Sialome and post-sialome perspectives. Annu. Rev. Entomol 2003;48:73-88. [PubMed: 12194906]

7. Champagne DE, Nussenzveig RH, Ribeiro JMC. Purification, partial characterization, and cloning of nitric oxide-carrying heme proteins (nitrophorins) from salivary glands of the blood-sucking insect Rhodnius prolixus. J. Biol. Chem 1995;270:8691-8695. [PubMed: 7721773]

8. Moreira MF, Coelho HSL, Zingali RB, Oliveira PL, Masuda H. Changes in salivary nitrophorin profile during the life cycle of the blood-sucking bug Rhodnius prolixus. Insect Biochem. Mol. Biol 2003;33:23-28. [PubMed: 12459197]

9. Ribeiro JMC, Nussenzveig RH. Nitric oxide synthase activity from a hematophagous insect salivary gland. FEBS Lett 1993;330:165-168. [PubMed: 7689981]

10. Nussenzveig RH, Bentley DL, Ribeiro JMC. Nitric oxide loading of the salivary nitric-oxide-carrying hemoproteins (nitrophorins) in the blood-sucking bug Rhodnius prolixus. J. Exp. Biol 1995;198:1093-1098. [PubMed: 8627144]

11. Yuda M, Hirai M, Miura K, Matsumura H, Ando K, Chinzei Y. cDNA cloning, expression and characterization of nitric-oxide synthase from the salivary glands of the blood-sucking insect Rhodnius prolixus. Eur. J. Biochem 1996;242:807-812. [PubMed: 9022713]

12. Soares AC, Carvalho-Tavares J, Gontijo N. d. F. dos Santos VC, Teixeira MM, Pereira MH. Salivation pattern of Rhodnius prolixus (Reduviidae; Triatominae) in mouse skin. J. Insect Physiol 2006;52:468-472. [PubMed: 16580013]

13. Ribeiro JMC, Hazzard JM, Nussenzveig RH, Champagne DE, Walker FA. Reversible binding of nitric oxide by a salivary heme protein from a bloodsucking insect. Science 1993;260:539-541. [PubMed: 8386393]

14. Hoshino M, Maeda M, Konishi R, Seki H, Ford PC. Studies on the reaction mechanism for reductive nitrosylation for ferrihemoproteins in buffer solutions. J. Am. Chem. Soc 1996;118:5702-5707.

15. Shokhireva, T. Kh.; Berry, RE.; Uno, E.; Balfour, CA.; Zhang, H.; Walker, FA. Electrochemical and NMR spectroscopic studies of distal pocket mutants of nitrophorin 2: Stability, structure, and dynamics of axial ligand complexes. Proc. Natl. Acad. Sci. U.S.A 2003;100:3778-3783. [PubMed: 12642672]

16. Ding XD, Weichsel A, Andersen JF, Shokhireva T. Kh. Balfour C, Pierik AJ, Averill BA, Montfort WR, Walker FA. Nitric oxide binding to the ferri- and ferroheme states of nitrophorin 1, a reversible NO-binding heme protein from the saliva of the blood-sucking insect, Rhodnius prolixus. J. Am. Chem. Soc 1999;121:128-138.

17. Traylor TG, Sharma VS. Why NO? Biochemistry 1992;31:2847-2849. [PubMed: 1348002]

18. Watt, AP.; Ennis, M. Characterization of histamine release by mast cells, basophils, and monocytes. In: Falus, A.; Grosman, N.; Darvas, Z., editors. Histamine: Biology and Medical Aspects. SpringMed Publishing Ltd.; Budapest (Hungary): 2004. p. 99-111.

19. Ribeiro JMC, Walker FA. High affinity histamine-binding and antihistaminic activity of the salivary nitric oxide-carrying heme protein (nitrophorin) of Rhodnius prolixus. J. Exp. Med 1994;180:22512257. [PubMed: 7964498]

20. Maes EM, Walker FA, Montfort WR, Czernuszewicz RS. Resonance Raman spectroscopic study of nitrophorin 1, a nitric oxide-binding heme protein from Rhodnius prolixus, and its nitrosyl and cyano adducts. J. Am. Chem. Soc 2001;123:1164-1172.

21. Berry RE, Ding XD, Shokhireva T. Kh. Weichsel A, Montfort WR, Walker FA. Axial ligand complexes of the Rhodnius nitrophorins: Reduction potentials, binding constants, EPR spectra, and structures of the 4-iodopyrazole and imidazole complexes of NP4. J. Biol. Inorg. Chem 2004;9:135144. [PubMed: 14673714] 
22. Shokhireva, T. Kh.; Smith, KM.; Berry, RE.; Shokhirev, NV.; Balfour, CA.; Zhang, H.; Walker, FA. Assignment of the ferriheme resonances of the high-spin forms of nitrophorins 1 and 4 by ${ }^{1} \mathrm{H}$ NMR spectroscopy: Comparison to structural data obtained from X-ray crystallography. Inorg. Chem 2007;46:170-178. [PubMed: 17198425]

23. Shokhireva, T. Kh.; Weichsel, A.; Smith, KM.; Berry, RE.; Shokhirev, NV.; Balfour, CA.; Zhang, H.; Montfort, WR.; Walker, FA. Assignment of the ferriheme resonances of the low-spin complexes of nitrophorins 1 and 4 by ${ }^{1} \mathrm{H}$ and ${ }^{13} \mathrm{C}$ NMR spectroscopy: Comparison to structural data obtained from X-ray crystallography. Inorg. Chem 2007;46:2041-2056. [PubMed: 17290983]

24. Shokhireva, T. Kh.; Shokhirev, NV.; Walker, FA. Assignment of heme resonances and determination of the electronic structures of high- and low-spin nitrophorin 2 by ${ }^{1} \mathrm{H}$ and ${ }^{13} \mathrm{C}$ NMR spectroscopy: An explanation of the order of heme methyl resonances in high-spin ferriheme proteins. Biochemistry 2003;42:679-693. [PubMed: 12534280]

25. Wegner P, Benda R, Schünemann V, Trautwein AX, Berry RE, Balfour CA, Wert D, Walker FA. Insect bites on a molecular basis. How does the blood-sucking bug Rhodnius prolixus get its meal? The ferriheme proteins nitrophorin 2 and 4 studied by Mössbauer spectroscopy. Hyperfine Interact 2002;C5:253-256.

26. Astashkin AV, Raitsimring AM, Walker FA. Two- and four-pulse ESEEM studies of the heme binding center of a low-spin ferriheme protein: The importance of a multi-frequency approach. Chem. Phys. Lett 1999;306:9-17.

27. Shokhireva, T. Kh.; Berry, RE.; Zhang, H.; Shokhirev, NV.; Walker, FA. Assignment of ferriheme resonances for high- and low-spin forms of nitrophorin 3 by ${ }^{1} \mathrm{H}$ and ${ }^{13} \mathrm{C}$ NMR spectroscopy and comparison to nitrophorin 2: Heme pocket structural similarities and differences. Inorg. Chim. Acta. 2007in press

28. Andersen JF, Ding XD, Balfour C, Shokhireva T. Kh. Champagne DE, Walker FA, Montfort WR. Kinetics and equilibria in ligand binding by nitrophorins 1-4: Evidence for stabilization of a nitric oxide-ferriheme complex through a ligand-induced conformational trap. Biochemistry 2000;39:10118-10131. [PubMed: 10956000]

29. Andersen JF, Champagne DE, Weichsel A, Ribeiro JMC, Balfour CA, Dress V, Montfort WR. Nitric oxide binding and crystallization of recombinant nitrophorin I, a nitric oxide transport protein from the blood-sucking bug Rhodnius prolixus. Biochemistry 1997;36:4423-4428. [PubMed: 9109649]

30. Maes EM, Weichsel A, Andersen JF, Shepley D, Montfort WR. Role of binding site loops in controlling nitric oxide release: Structure and kinetics of mutant forms of nitrophorin 4. Biochemistry 2004;43:6679-6690. [PubMed: 15157102]

31. Weichsel A, Andersen JF, Champagne DE, Walker FA, Montfort WR. Crystal structures of a nitric oxide transport protein from a blood-sucking insect. Nat. Struc. Biol 1998;5:304-309.

32. Andersen JF, Montfort WR. The crystal structure of nitrophorin 2. A trifunctional antihemostatic protein from the saliva of Rhodnius prolixus. J. Biol. Chem 2000;275:30496-30503. [PubMed: 10884386]

33. Andersen JF, Weichsel A, Balfour CA, Champagne DE, Montfort WR. The crystal structure of nitrophorin 4 at $1.5 \AA$ resolution: Transport of nitric oxide by a lipocalin-based heme protein. Structure 1998;6:1315-1327. [PubMed: 9782054]

34. Weichsel A, Andersen JF, Roberts SA, Montfort WR. Nitric oxide binding to nitrophorin 4 induces complete distal pocket burial. Nat. Struc. Biol 2000;7:551-554.

35. Roberts SA, Weichsel A, Qiu Y, Shelnutt JA, Walker FA, Montfort WR. Ligand-induced heme ruffling and bent NO geometry in ultra-high-resolution structures of nitrophorin 4. Biochemistry 2001;40:11327-11337. [PubMed: 11560480]

36. Montfort WR, Weichsel A, Andersen JF. Nitrophorins and related antihemostatic lipocalins from Rhodnius prolixus and other blood-sucking arthropods. Biochim. Biophys. Acta 2000;1482:110-118. [PubMed: 11058753]

37. Ribeiro JMC, Andersen JF, Silva-Neto MAC, Pham VM, Garfield MK, Valenzuela JG. Exploring the sialome of the blood-sucking bug Rhodnius prolixus. Insect Biochem. Mol. Biol 2004;34:61-79. [PubMed: 14976983] 
38. Andersen JF, Gudderra NP, Francischetti IMB, Valenzuela JG, Ribeiro JMC. Recognition of anionic phospholipid membranes by an antihemostatic protein from a blood-feeding insect. Biochemistry 2004;43:6987-6994. [PubMed: 15170336]

39. Andersen JF, Gudderra NP, Francischetti IMB, Ribeiro JMC. The role of salivary lipocalins in blood feeding by Rhodnius prolixus. Arch. Insect Biochem. Physiol 2005;58:97-105. [PubMed: 15660358]

40. Callahan MK, Williamson P, Schlegel RA. Surface expression of phosphatidylserine on macrophages is required for phagocytosis of apoptotic thymocytes. Cell Death Diff 2000;7:645-653.

41. Hirt UA, Leist M. Rapid, noninflammatory and PS-dependent phagocytic clearance of necrotic cells. Cell Death Diff 2003;10:1156-1164.

42. Ignarro LJ. Biosynthesis and metabolism of endothelium-derived nitric oxide. Annu. Rev. Pharmacol. Toxicol 1990;30:535-560. [PubMed: 2188578]

43. Weichsel A, Maes EM, Andersen JF, Valenzuela JG, Shokhireva T. Kh. Walker FA, Montfort WR. Heme-assisted S-nitrosation of a proximal thiolate in a nitric oxide transport protein. Proc. Natl. Acad. Sci. U.S.A 2005;102:594-599. [PubMed: 15637157]

44. Berry RE, Shokhireva T. Kh. Filippov I, Shokhirev MN, Zhang H, Walker FA. The effect of the Nterminus on heme cavity structure, ligand equilibrium and rate constants and reduction potentials of nitrophorin 2 from Rhodnius prolixus. Biochemistry 2007;46:6830-6843. [PubMed: 17506528]

45. Knipp M, Zhang H, Berry RE, Walker FA. Overexpression in Escherichia coli and functional reconstitution of the liposome binding ferriheme protein nitrophorin 7 from the blood sucking bug Rhodnius prolixus. Prot. Expr. Purif 2007;54:183-191.

46. Zhang X, Cardossa L, Broderick M, Fein H, Davies IR. Novel calibration method for nitric oxide microsensors by stoichiometric generation of nitric oxide from SNAP. Electroanalysis 2000;12:425428.

47. Edgar RC. MUSCLE: Multiple sequence alignment with high accuracy and high throughput. Nucleic Acids Res 2004;32:1792-1797. [PubMed: 15034147]

48. Schwede T, Kopp J, Guex N, Peitsch MC. SWISS-MODEL: An automated protein homologymodeling server. Nucl. Acid Res 2003;31:3381-3385.

49. Peitsch MC. Protein modeling by E-mail. Bio/Technology 1995;13:658-660.

50. Guex N, Peitsch MC. SWISS-MODEL and the Swiss-PdbViewer: An environment for comparative protein modeling. Electrophoresis 1997;18:2714-2723. [PubMed: 9504803]

51. Hooft RW, Vriend G, Sander C, Abola EE. Errors in protein structures. Nature 1996;381:272. [PubMed: 8692262]

52. Laskowski RA, MacArthur MW, Moss D, Thornton JM. PROCHECK: A program to check the stereochemical quality of protein structures. J. Appl. Cryst 1993;26:283-291.

53. Ribeiro JMC, Schneider M, Guimarães JA. Purification and characterization of prolixin S (nitrophorin 2), the salivary anticoagulant of the blood-sucking bug Rhodnius prolixus. Biochem. J 1995;308:243249. [PubMed: 7755571]

54. Nielsen H, Engelbrecht J, Brunak S, von Heijne G. Identification of prokaryotic and eukaryotic signal peptides and prediction of their cleavage sites. Prot. Eng 1997;10:1-6.

55. Bendtsen JD, Nielsen H, von Heijne G, Brunak S. Improved prediction of signal peptides: SignalP 3.0. J. Mol. Biol 2004;340:783-795. [PubMed: 15223320]

56. Nielsen, H.; Krogh, A. Proceedings of the Sixth International Conference on Intelligent Systems for Molecular Biology (ISMB 6). AAAI Press; Menio Park, California: 1998. p. 122-130.

57. Jochem, J.; Żwirska-Korczala, KW. Histamine In the cardiovascular system. In: Falus, A.; Grosman, N.; Darvas, Z., editors. Histamine: Biology and Medical Aspects. SpringMed Publishing Ltd.; Budapest (Hungary): 2004. p. 303-316.

58. Yoshimura T. Q-Band electron paramagnetic resonance study of nitrosylprotoheme dimethyl ester complexes with N-, O-, and S-donor ligand as model systems for nitrosylhemoproteins. J. Inorg. Biochem 1983;18:263-277.

59. Brunori M, Falcioni G, Rotilio G. Kinetic properties and electron paramagnetic resonance spectra of the nitric oxide derivative of hemoglobin components of trout (Salmo irideus). Proc. Natl. Acad. Sci. U. S. A 1974;71:2470-2472. [PubMed: 4366769] 
60. Cheng, L.; Richter-Addo, GB. Binding and activation of nitric oxide by metalloporphyrins and heme. In: Kadish, KM.; Smith, KM.; Guilard, R., editors. The Porphyrin Handbook. 4. Academic Press; San Diego (California): 2000. p. 219-291.

61. Wittung-Stafshede P, Mamström BG, Winkler JR, Gray HB. Folding of deoxymyglobin triggered by electron transfer. J. Phys. Chem. A 1998;102:5599-5601.

62. Wittung-Stafshede P. Effect of redox state on unfolding energetics of heme proteins. Biochim. Biophys. Acta 1999;1432:401-405. [PubMed: 10407162]

63. Yatsunyk LA, Carducci MD, Walker FA. Low-spin ferriheme models of the cytochromes: Correlation of molecular structure with EPR spectral type. J. Am. Chem. Soc 2003;125:15986-16005. [PubMed: 14677991]

64. La Mar GN, Burns PD, Jackson JT, Smith KM, Langry KC, Strittmatter P. Proton magnetic resonance determination of the relative heme orientations in disordered native and reconstituted ferricytochrome $b_{5}$. Assignment of heme resonances by deuterium labeling. J. Biol. Chem 1981;256:6075-6079. [PubMed: 7240191]

65. Walker FA, Emrick D, Rivera JE, Hanquet BJ, Buttlaire DH. Effect of heme orientation on the reduction potential of cytochrome $b_{5}$. J. Am. Chem. Soc 1988;110:6234-6240.

66. Yoshimura T, Suzuki S. The $\mathrm{pH}$ dependence of the stereochemistry around the heme group in NOcytochrome $c$ (horse heart). Inorg. Chim. Acta 1988;152:241-249.

67. Suzuki S, Yoshimura T, Nakahara A, Iwasaki H, Shidara S, Matsubara T. Electronic and magnetic circular dichroism spectra of pentacoordinate nitrosulhemes in cytochromes $c^{\prime}$ from nonphotosynthetic bacteria and their model complexes. Inorg. Chem 1987;26:1006-1008.

68. Iwasaki H, Yoshimura T, Suzuki S, Shidara S. Spectral properties of Achromobacter xylosoxidans cytochrome $c^{\prime}$ and their NO complexes. Biochim. Biophys. Acta 1991;1058:79-82. [PubMed: 1646026]

69. Yoshimura T, Fujii S, Kamada H, Yamaguchi K, Suzuki S, Shidara S, Takakuwa S. Spectroscopic characterization of nitrosylheme in nitric oxide complexes of ferric and ferrous cytochrome $c^{\prime}$ from photosynthetic bacteria. Biochim. Biophys. Acta 1996;1292:39-46. [PubMed: 8547347]

70. Sharma VS, Madge D. Activation of soluble guanylate cyclase by carbon monoxide and nitric oxide: A mechanistic model. Methods 1999;19:494-505. [PubMed: 10581149]

71. Hobbs AJ. Soluble guanylate cyclase: The forgotten sibling. Trends Pharmacol. Sci 1997;18:484491. [PubMed: 9458697]

72. Burstyn JN, Yu AE, Dierks EA, Hawkins BK, Dawson JH. Studies of the heme coordination and ligand binding properties of soluble guanylate cyclase (sGC): Characterization of $\mathrm{Fe}(\mathrm{II}) \mathrm{sGC}$ and $\mathrm{Fe}$ (II)sGC(CO) by electronic absorption and magnetic circular dichroism spectroscopy and failure of CO to activate the enzyme. Biochemistry 1995;34:5896-5903. [PubMed: 7727447]

73. Fasman, CD. Handbook of Biochemistry and Molecular Biology. 3rd ed.. CRC Press; Boca Raton (FL): 1976.

74. Dierks EA, Burstyn JN. The deactivation of soluble guanylyl cyclase by redox-active agents. Arch. Biochem. Biophys 1998;351:1-7. [PubMed: 9500837]

75. Kharitonov VG, Sharma VS, Magde D, Koesling D. Kinetics of nitric oxide dissociation from fiveand six-coordinate nitrosyl hemes and heme proteins, including soluble guanylate cyclase. Biochemistry 1997;36:6814-6818. [PubMed: 9184164] 


\begin{tabular}{|c|c|c|c|c|}
\hline \multirow{2}{*}{ native: } & NP2 & : & $\mathrm{DC} \ldots(2)^{a}$ & (7) \\
\hline & NP4 & : & AC.... (2) & $(7)$ \\
\hline \multirow[t]{6}{*}{ recombinant: } & NP2 & : & MDC...(2) & (44) \\
\hline & GSHM - NP 2 & & HMDC...(2) & (44) \\
\hline & NP2 (D1A) & : & AC... (2) & (44) \\
\hline & NP 4 & : & $\mathrm{AC} \ldots(2)$ & (34) \\
\hline & wt NP7 & & PGEC...(5) & this work \\
\hline & $\operatorname{NP} 7(\Delta 1-3)$ & & MEC...(5) & this work \\
\hline
\end{tabular}

${ }^{a}$ The numbers in parenthesis refer to the positions of the last residues displayed here in the amino acid sequences of the mature proteins (compare Figure 1).

Scheme 1.

N-Terminal Amino Acid Sequences of Native and Recombinant $R$. prolixus NP2, NP4, and NP7, and Their N-Terminal Mutants. 


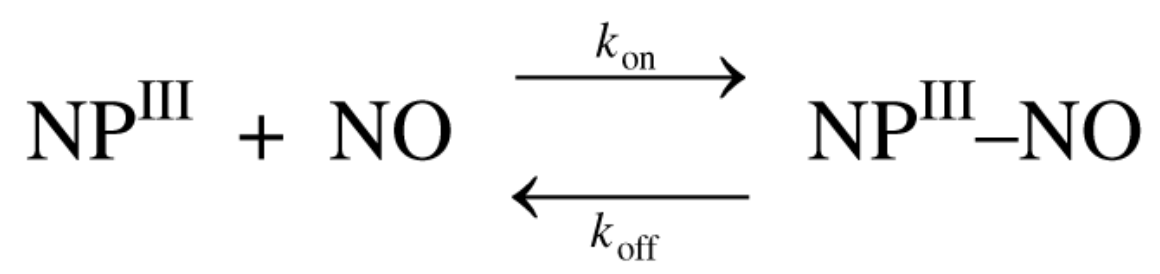

Scheme 2. 


$$
\mathrm{NP}^{\mathrm{III}}-\mathrm{NO}+\mathrm{ImH} \underset{k_{\text {on }}}{\stackrel{k_{\text {off }}}{\longrightarrow}} \mathrm{NP}^{\mathrm{III}}+\mathrm{NO}+\mathrm{ImH} \stackrel{k^{\mathrm{ImH}}}{\longrightarrow} \mathrm{NP}^{\mathrm{III}}-\mathrm{ImH}+\mathrm{NO}
$$

Scheme 3. 


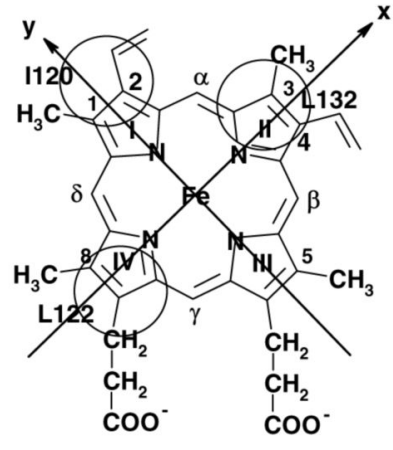

$\underline{A}$

NP7:

Mainly $\underline{A}$

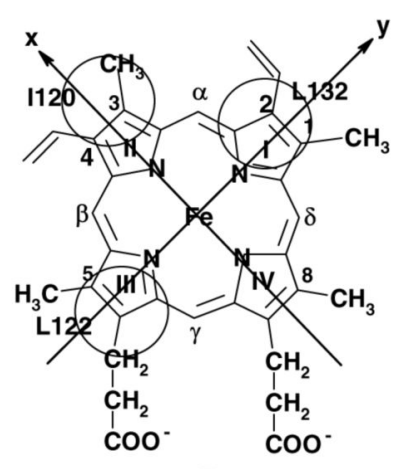

$\underline{B}$

Mainly $\underline{B}$

${ }^{a}$ The view is from above the distal side, with His-57 behind the heme. Substituents on the periphery of the heme are numbered clockwise from $1-\mathrm{CH}_{3}$ to $8-\mathrm{CH}_{3}$ for the $\mathbf{A}$ orientation, and counterclockwise for the $\mathbf{B}$ orientation. Circles denote the position of three distal side chains that point onto the heme plane in the approximate positions shown $(15,32)$.

Scheme 4.

Chemical Structure and Numbering of the A and B Heme Orientations in R. prolixus NP2. ${ }^{a}$ 
$$
\mathrm{NP}-\mathrm{His}: \mathrm{N}^{\varepsilon}-\mathrm{Fe}^{\mathrm{II}}(\mathrm{ppIX})-\mathrm{NO}+\mathrm{H}^{+} \longrightarrow \mathrm{NP}-\mathrm{His}: \mathrm{N}^{\varepsilon}-\mathrm{H}^{+}+\mathrm{Fe}^{\mathrm{II}}(\mathrm{ppIX})-\mathrm{NO}
$$ \\ ${ }^{a}$ ppIX = protoporphyrin IX.}

Scheme 5.

Proposed $\mathrm{H}^{+}-$Mediated Breaking of the His: $\mathrm{N}^{\varepsilon}-\mathrm{Fe}^{\mathrm{II}}$ Bond in $R$. prolixus $\mathrm{NP} 2,3$, and 7 at $\mathrm{pH}$ 5.5. ${ }^{a}$ 


\begin{tabular}{|c|c|c|c|c|c|c|c|c|}
\hline & & $1 \underline{0}$ & $2 \underline{0}$ & $3 \underline{0}$ & $4 \underline{0}$ & $5 \underline{0}$ & $6 \underline{0}$ & \\
\hline NP1 & : & MKSYTALLAV & AILCLFAAVG & VSGKCTKNĀ & AQTGFNKDKY & FNGDVWYVTD & YLDLEPDDV $\bar{P}$ & (37) \\
\hline JP2 & : & MELYTALLAV & TILCLTSTMG & VSGDCSTNIS & PKQGLDKAKY & FSG - KWYVTH & FLDKDP - QVT & (35) \\
\hline & & & & & $\alpha_{1}$ & $\beta_{\mathrm{A}}$ & | - AB - 1oop & \\
\hline P3 & : & MEPYSALLAV & TILCLTSTMG & VSGDCSTNIS & PKKGLDKAKY & FSG - TWYVTH & YLDKDP - QVT & \\
\hline P4 & : & MKSYTSLLAV & AILCLF - - GG & VNGACTKNAI & AQTGFNKDKY & FNGDVWYVTD & YLDLEPDDVP & \\
\hline \multirow[t]{3}{*}{ P7 } & : & MELYTALLAV & TILSPSSIVG & LPGECSVNVI & PKKNLDKAKF & FSG - TWYETH & YLDMDP - QAT & \\
\hline & & & & & $\overline{\alpha_{1}}$ & $\beta_{\mathrm{A}}$ & $\mid A B-100 p$ & \\
\hline & & $7 \underline{0}$ & $8 \underline{0}$ & $9 \underline{0}$ & $10 \underline{0}$ & $11 \underline{0}$ & $12 \underline{0}$ & \\
\hline P1 & : & KRYCAALAA $\overline{\mathrm{G}}$ & TASGKLKEA $\bar{L}$ & YHYDPKTQDT & FYDVSELQEE & SPG - KYTANF & 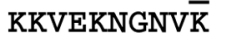 & \\
\hline \multirow[t]{2}{*}{ NP2 } & : & DQYCSSFTPR & ESDGTVKEAL & YHYNANKKTS & FYNIGEGKLE & SSGLQYTAKY & KTVDKKKAVL & \\
\hline & & $-\overline{\beta_{B}}$ & $\overline{\beta_{\mathrm{C}}}$ & & $\beta_{D}$ & $\beta_{\mathrm{E}}$ & $\overline{ } \overline{\beta_{E}^{\prime}}$ & \\
\hline P3 & $:$ & DPYCSSFTPK & ESGGTVKEAL & YHFNSKKKTS & FYNIGEGKLG & SSGVQYTAKY & NTVDKKRKEI & $y$ \\
\hline P4 & : & KRYCAALAAG & TASGKLKEAL & YHYDPKTQDT & FYDVSELQVE & SLG - KYTANF & KKVDKNGNVK & \\
\hline \multirow[t]{3}{*}{ NP7 } & : & EKFCFSFAPR & ESGGTVKEAL & YHFNVDSKVS & FYNTGTGPLE & SNGAKYTAKF & NTVDKKGKEI & (98 \\
\hline & & $-\bar{l} \beta_{B}$ & $\overline{\beta_{\mathrm{C}}}$ & & $\overline{\beta_{D}}$ & $\beta_{E}$ & $\overline{ } \overline{\beta_{E}^{\prime}}$ & \\
\hline & & $13 \underline{0}$ & $14 \underline{0}$ & $15 \underline{0}$ & $16 \underline{0}$ & $17 \underline{0}$ & $18 \underline{0}$ & \\
\hline P1 & : & VDVTSGNYYT & ADDSS & ALIHTCLHKG & NKDLGDLYAV & LNRNKDTNAG & DKVKGAVTA $\bar{A}$ & 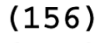 \\
\hline \multirow[t]{2}{*}{ NP2 } & : & KEADEKNSYT & LTVLEADDSS & ALVHICLREG & SKDLGDLYTV & LTHQKDAEPS & AKVKSAVTQA & $(15$ \\
\hline & & & $\overline{B_{F}}$ & \begin{tabular}{l|l}
$\beta_{G}$ & $G$
\end{tabular} & HH - loop $\overline{\beta_{1}}$ & & $\alpha_{2}$ & \\
\hline P3 & : & EPADPKDSYT & LTVLEADDSS & ALVHICLREG & PKDLGDLYTV & LSHQKTGEPS & ATVKNAVAQA & \\
\hline P4 & : & VAVTAGNYYT & FTVMYADDSS & ALIHTCLHKG & NKDLGDLYAV & LNRNKDAAAG & DKVKSAVSAA & \\
\hline \multirow[t]{3}{*}{ NP7 } & : & KPADEKYSYT & VTVIEAAKQS & ALIHICLQED & GKDIGDLYSV & LNRNKNALPN & KKIKKALNKV & \\
\hline & & & $\overline{B_{F}}$ & $\beta_{\mathrm{G}} \quad \mathrm{G}$ & H - loop $\quad \beta_{\mathrm{r}}$ & & $\overline{\alpha_{2}}$ & \\
\hline & & $19 \underline{0}$ & $20 \underline{0}$ & \multicolumn{5}{|c|}{ calculated pI: } \\
\hline P1 & : & SLKFSDFIST & KDNKCEYDNV & SLKSLLTK & $184)$ & 6.35 & & \\
\hline \multirow[t]{2}{*}{ NP2 } & $:$ & GLQLSQFVGT & 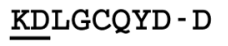 & QFTSL & 179) & 6.11 & & \\
\hline & & $\overline{\alpha_{3}}$ & $\overline{\beta_{\mathrm{H}}{ }^{\prime}}$ & $\overline{\alpha_{4}}$ & & & & \\
\hline P3 & $:$ & GLKLNDFVDT & KTLSCTYD - D & QFTSM & $179)$ & 6.48 & & \\
\hline 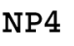 & : & TLEFSKFIST & KENNCAYDND & SLKSLLTK & $184)$ & 6.35 & & \\
\hline JP7 & : & SLVLTKFVVT & $\frac{\mathrm{KDLDCKYD}-\mathrm{D}}{\boldsymbol{\beta}^{\prime}}$ & KFLSSWQK & 185) & 9.21 & & \\
\hline
\end{tabular}

Figure 1.

Amino acid sequence alignment of Rhodnius prolixus NP1 (Swiss-Prot code Q26239), NP2 (Swiss-Prot code Q26241), NP3 (Swiss-Prot code Q94733), NP4 (Swiss-Prot code Q94734), and NP7 (TrEMBL code Q6PQK2). Signal sequences for secretion are displayed in gray. The amino acid residue numbering at the end of each line is for the truncated forms throughout this article. The proximal His is indicated by *. The secondary structure elements $\alpha$-helices $(\alpha)$ and $\beta$-sheets $(\beta)$ are given based on the crystal structure of NP2 (PDB code 1EUO) (32) and the homology model of NP7 and were derived using DEEPVIEw V3.7 (this work; compare Figure 7). The theoretical pIs of the mature proteins (i.e., with truncated signal peptides), taking the two disulfides into account, were calculated at http://www.expasy.ch/tools/pi_tool.html/. 


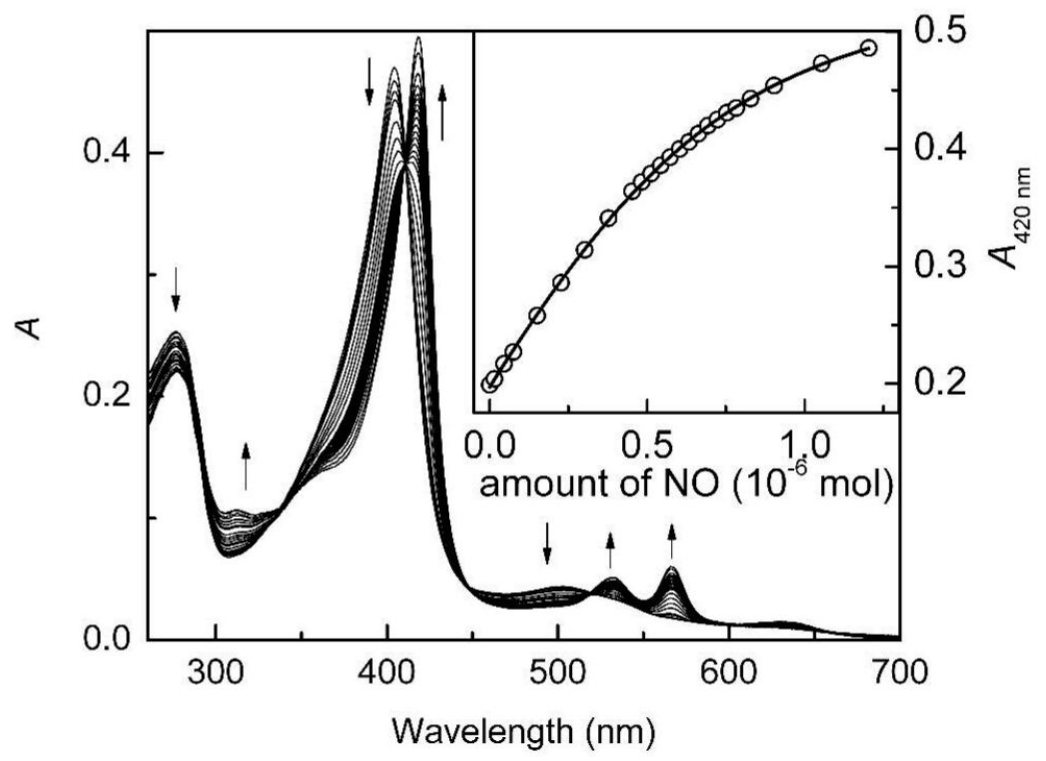

Figure 2.

Titration of $w t$ NP7 from $R$. prolixus in $100 \mathrm{mM}$ MOPS/NaOH (pH 7.5) with NO at $25 \pm 1^{\circ}$ C. SNAP was used as an NO donor and the presence of $\mathrm{Cu}^{\mathrm{I}}$ ions catalyzed the immediate decomposition of the $S$-nitrosothiol SNAP according to $2 \mathrm{R}-\mathrm{S}-\mathrm{N}=\mathrm{O} \rightarrow \mathrm{R}-\mathrm{S}-\mathrm{S}-\mathrm{R}+2 \mathrm{NO}$. 


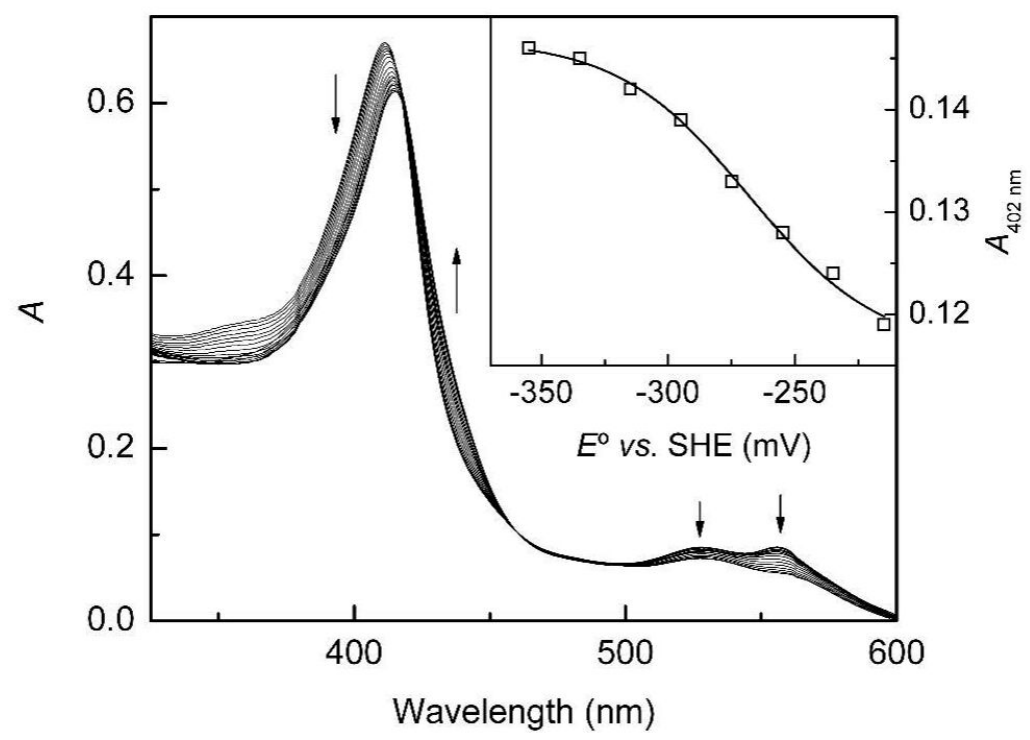

Figure 3.

Electrochemical titration of the $w t$ NP7-Hm complex in $100 \mathrm{mM}$ MOPS/NaOH (pH 7.5) at 27 $\pm 1{ }^{\circ} \mathrm{C}$ in the presence of the electrochemical mediators methyl viologen, anthraquinone-2sulfonic acid, and $\mathrm{Ru}\left(\mathrm{NH}_{3}\right)_{6} \mathrm{Cl}_{3}$ (each $\left.\sim 200 \mu \mathrm{M}\right)$. 


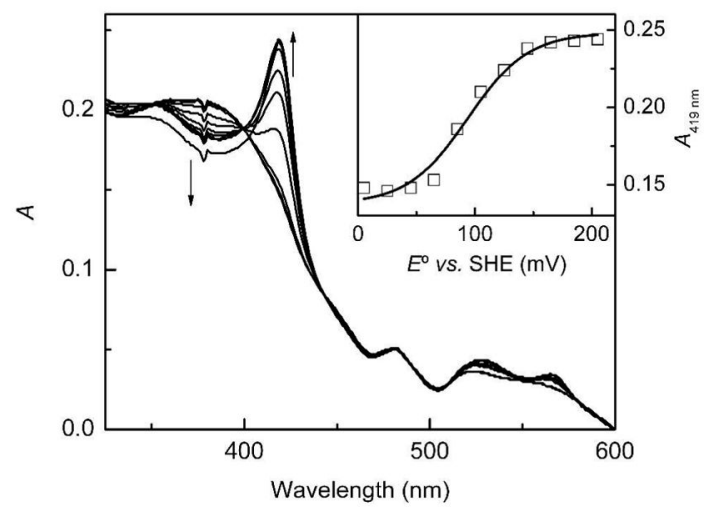

Figure 4A

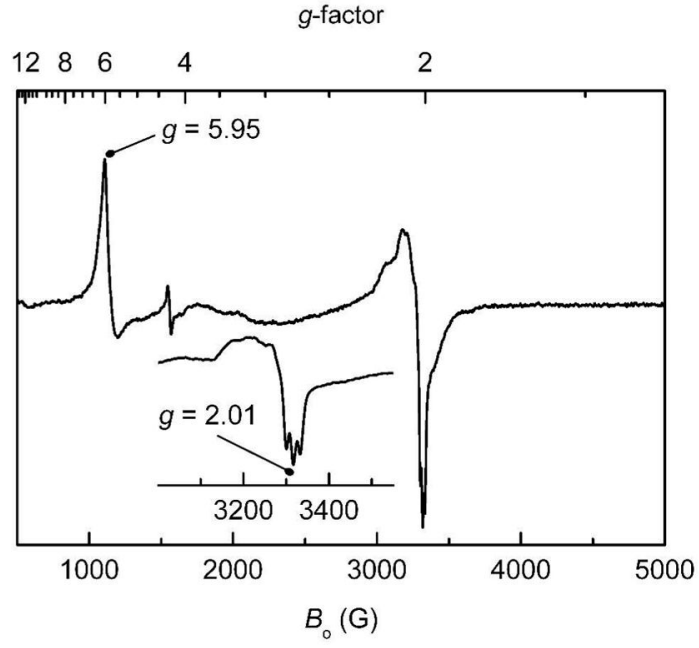

Figure 4B

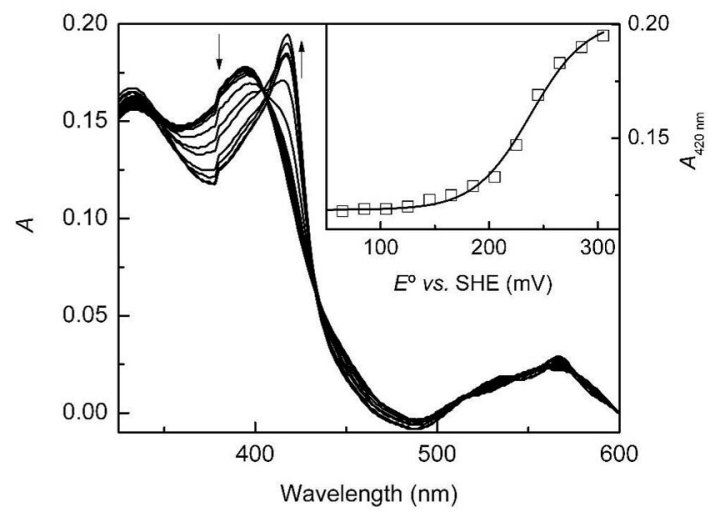

Figure 4C

Figure 4.

Spectroelectrochemistry and EPR spectroscopy of NP7-NO complexes. (A) UV-visible spectra of $w t \mathrm{NP} 7-\mathrm{NO}$ in $100 \mathrm{mM} \mathrm{NaH}{ }_{2} \mathrm{PO}_{4} / \mathrm{NaOH}(\mathrm{pH} 5.5)$ as a function of applied potential $(-200,-180,-160,-140,-120,-100,-80,-60,-40,-20$, and $0 \mathrm{mV} v s . \mathrm{Ag} / \mathrm{AgCl}$; add 205 $\mathrm{mV}$ for potential $v s$. SHE). Inset: Fit of the spectroelectrochemical data. (B) EPR spectrum of $w t \mathrm{NP}^{\mathrm{II}}-\mathrm{NO}$ in $50 \mathrm{mM} \mathrm{NaOAc} / \mathrm{HOAc}(\mathrm{pH} 5.0)$ recorded at $4.2 \mathrm{~K}$ at X-band. Other than a small amount of high-spin $\mathrm{Fe}^{\mathrm{III}}\left(g_{\|}=5.95\right)$ originating from unligated NP7, the signal is characteristic of 5-coordinate $\mathrm{Fe}^{\mathrm{II}}-\mathrm{NO}$ heme centers $\left(g_{\text {iso }}=2.01\right.$; see Inset for detailed resolution) (58,59). (C) UV-visible spectra of NP7( $\Delta 1-3)-\mathrm{NO}$ in $100 \mathrm{mM}$ MOPS/NaOH $(\mathrm{pH}$ $7.5)$ as a function of applied potential $(-140,-120,-100,-80,-60,-40,-20,0,+20,+40$, $+60,+80$, and $100 \mathrm{mV} v s$. Ag/ $\mathrm{AgCl}$; add $205 \mathrm{mV}$ for potential $v s$. SHE). Inset: Fit of the spectroelectrochemical data. 


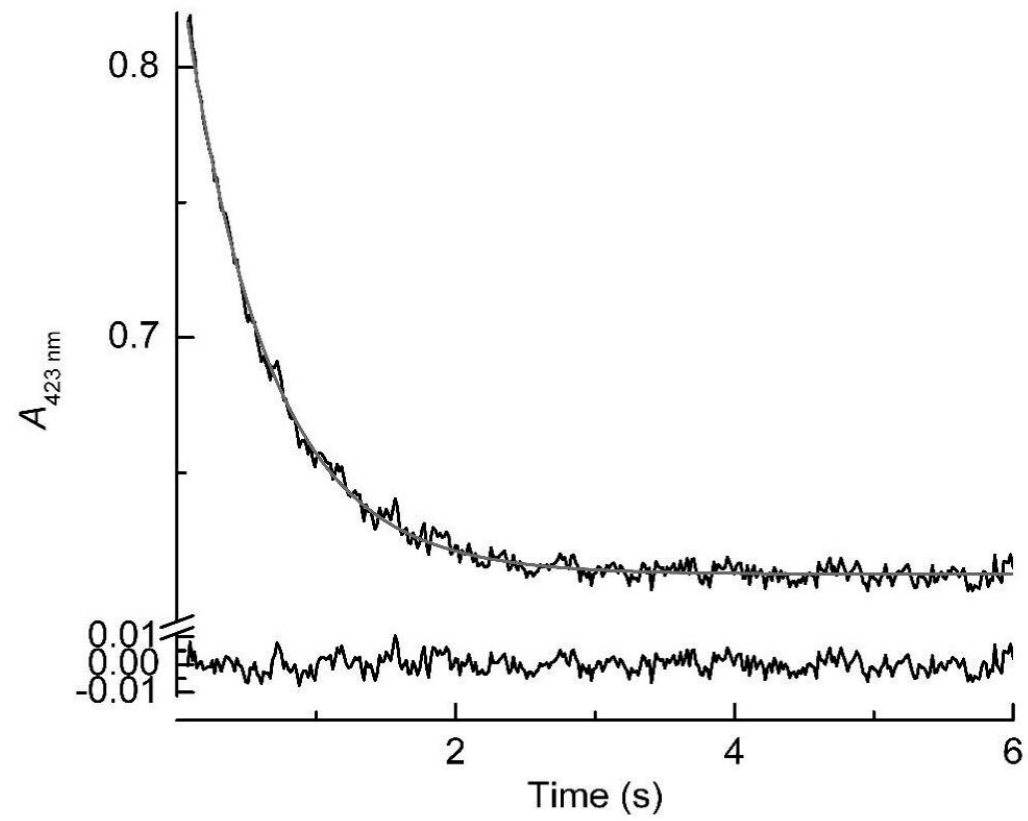

Figure 5.

Stopped-flow kinetics measurement of the ImH displacement of NO bound to wt NP7 in 100 $\mathrm{mM}$ MOPS/NaOH $\left(\mathrm{pH} \mathrm{7.5)}\right.$ at $25^{\circ} \mathrm{C}$. Absorption at $423 \mathrm{~nm}$ was monitored and the data (black) fitted with a first-order model (gray). The residual is displayed at the bottom. 


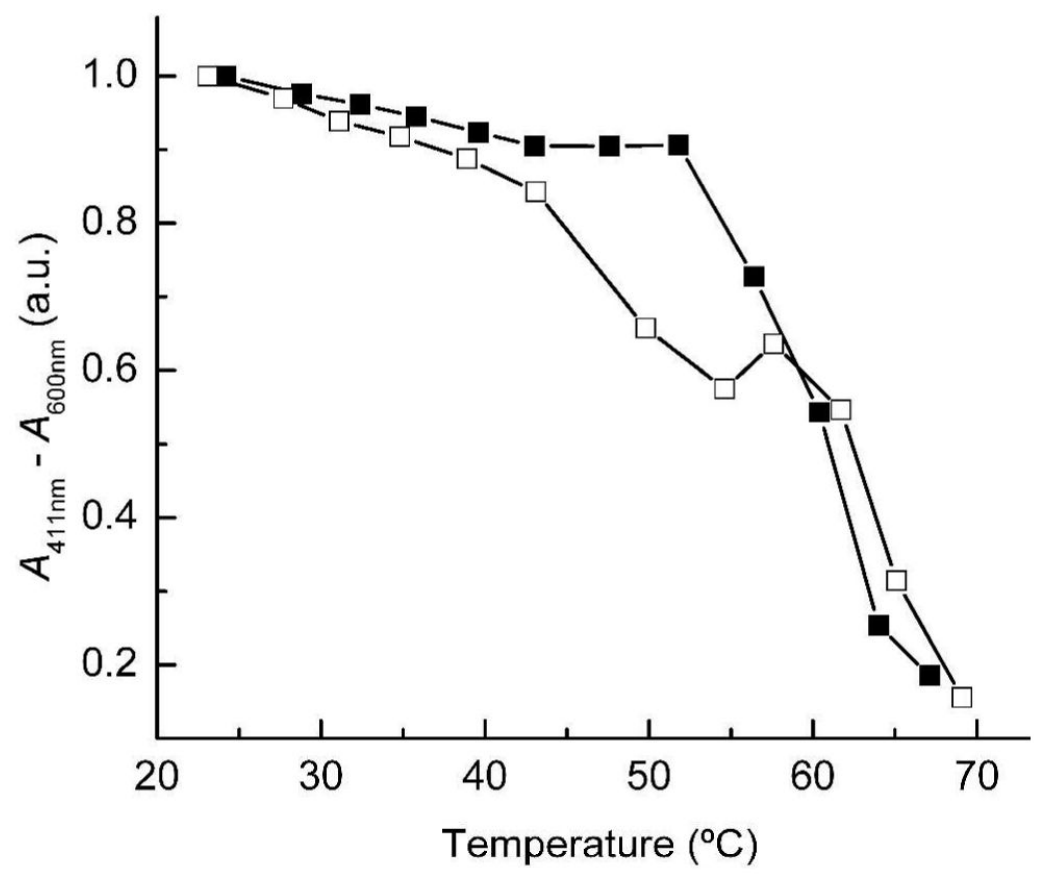

Figure 6.

Thermal stability of $w t$ NP7-ImH ( $\bullet$ ) and NP7( $\Delta 1-3)-\operatorname{ImH}(\square)$ in $30 \mathrm{mM} \mathrm{NaH}{ }_{2} \mathrm{PO}_{4} / \mathrm{NaOH}$ (pH 5.5). Temperature was increased in $\sim 5^{\circ} \mathrm{C}$ steps and then the sample equilibrated for $5 \mathrm{~min}$ after the temperature was reached. Subsequently, absorption spectra were recorded between 300 and $600 \mathrm{~nm}$. To account for the formation of precipitate at higher temperature, the apparent absorption at $600 \mathrm{~nm}$ was subtracted from the absorption at $411 \mathrm{~nm}$ and the difference values plotted vs. temperature. 


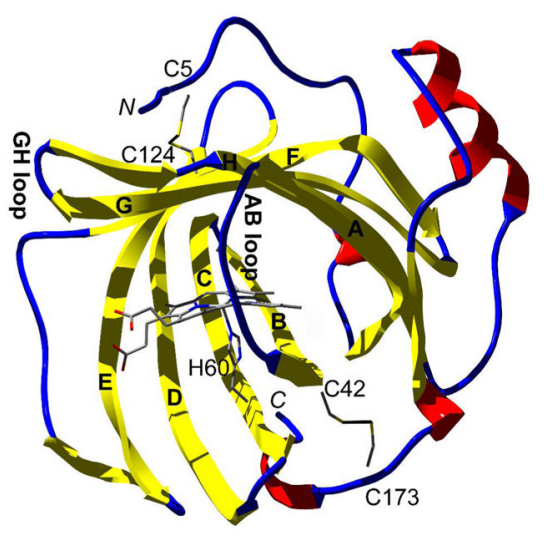

Figure 7A

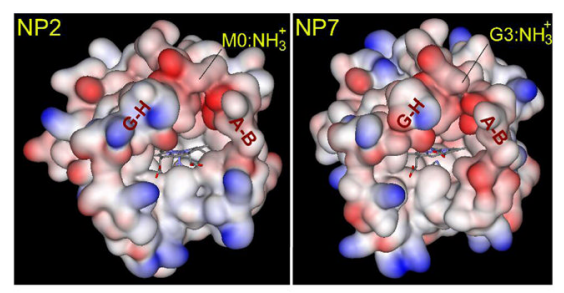

Figure 7B

Figure 7.

Homology model of NP7(G3-S182) from $R$. prolixus with 2,4-dimethyl deuteroporphyrin (symmetrical heme) based on the crystal structure of NP2 (RMSD $=0.39 \AA$ ) and on the sequence alignment given in Figure 1. (A) Ribbon diagram of the NP7(G3-S182) homology model. In agreement with Figure 1, the main $\beta$-strands are designated $\mathrm{A}$ to $\mathrm{H}$ in bold letters and the $\mathrm{A}-\mathrm{B}$ and $\mathrm{G}-\mathrm{H}$ loops are mentioned. The $\mathrm{N}$ - and the $\mathrm{C}$-terminus are designated in cursive letters $N$ and $C$. The four disulfide forming Cys residues, the heme cofactor, and the proximal His-60 are displayed as stick models. (B) Surface representations of the heme entrance site of (left) NP2 (PDB code 1EUO) (32) and (right) the homology model of NP7(G3-S182) (this work). The molecules are oriented $90^{\circ}$ counterclockwise compared to Figure 7A. The surface electrostatic potential is indicated in blue (positive) and red (negative). The heme and the proximal His were left out of the surface calculation and are displayed individually as stick models. Figures were prepared with DEEPVIEw V3.7 and rendered with POV-ray V3.6 (http://www.povray.org) (A) or viewERLITE V5.0 (B). 


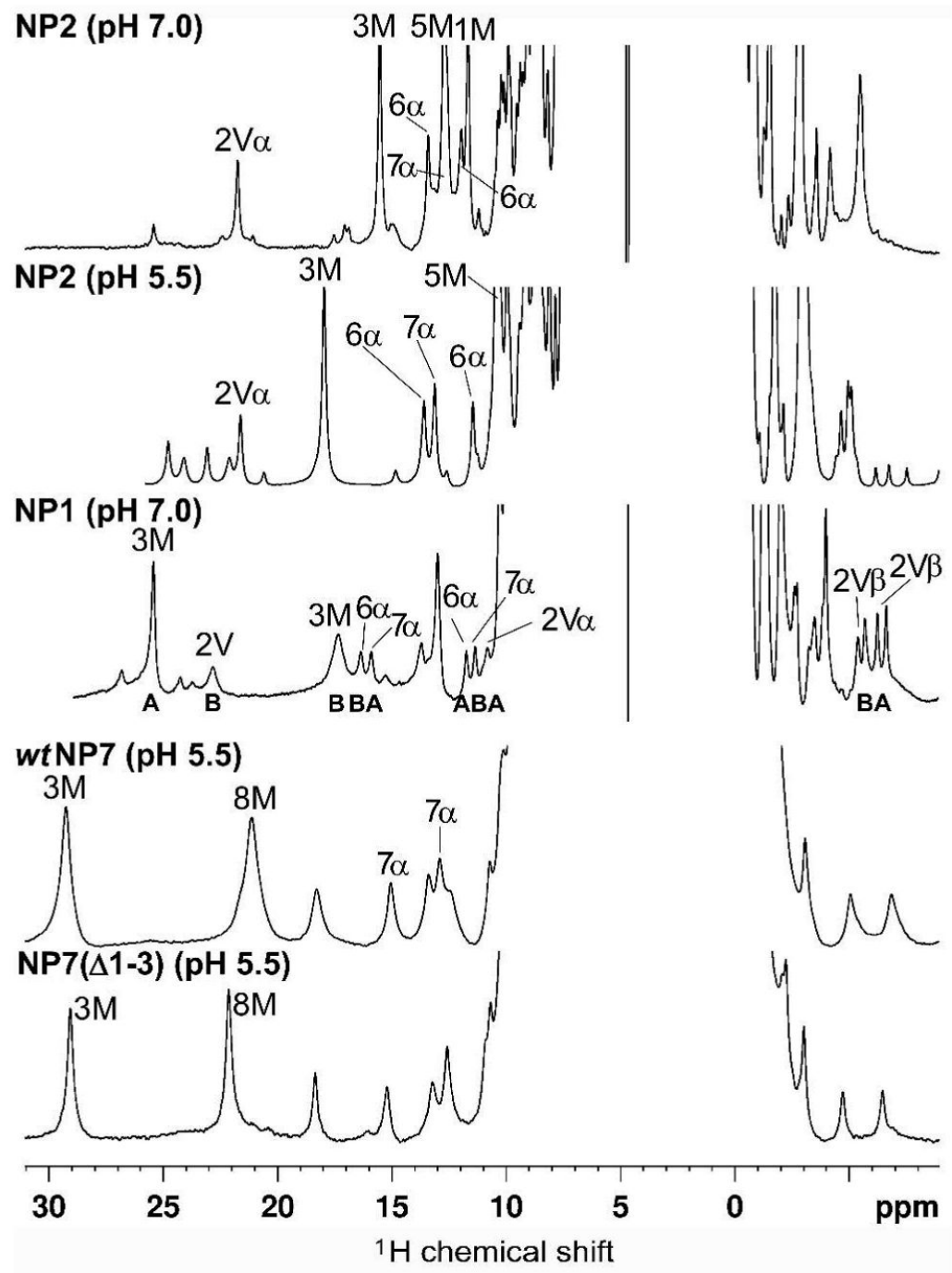

Figure 8.

${ }^{1} \mathrm{H}$ NMR spectra of NP2-ImH at $\mathrm{pH}^{*} 7.0$ and 5.5, NP1-ImH at $\mathrm{pH}^{*} 7.0$, and $w t$ NP7-ImH and NP7 $(\Delta 1-3)-\operatorname{ImH}$, both at $\mathrm{pH}^{*} 5.5$. The proteins were dissolved in $30 \mathrm{mM} \mathrm{NaD} \mathrm{PO}_{4} / \mathrm{NaOD}$ $\left(\mathrm{pH}^{*} 7.0\right)$ or $30 \mathrm{mM} \mathrm{Na} 2 \mathrm{DPO}_{4} /$ acetic acid- $d_{4}\left(\mathrm{pH}^{*} 5.5\right)$, respectively, at concentrations of 1 $2 \mathrm{mM} .5 \mathrm{mM}$ of ImD/acetic acid- $d_{4}\left(\mathrm{pH}^{*} 7.0\right.$ or $\left.\mathrm{pH}^{*} 5.5\right)$ were added and spectra were recorded at $25^{\circ} \mathrm{C}$. The chemical shift assignments for NP2-ImH and NP1-ImH at pH* 7.0 are from previous literature $(23,24)(1 \mathrm{M}, 3 \mathrm{M}, 5 \mathrm{M}, 8 \mathrm{M}$ : heme methyl groups; $2 \mathrm{~V} \alpha$ and $2 \mathrm{~V} \beta$ : heme vinyl group $\mathrm{C}^{\alpha} \mathrm{H}$ and $\mathrm{C}^{\beta} \mathrm{H}_{2}$, respectively; $6 \alpha, 7 \alpha$, propionate-group $\mathrm{C}^{\alpha} \mathrm{H}_{2}$; numbering corresponds to the pyrrole ring $\beta$ carbons according to Scheme 4 . $\mathbf{A}$ and $\mathbf{B}$ designate the two different heme orientations that have been assigned for NP1-ImH). 


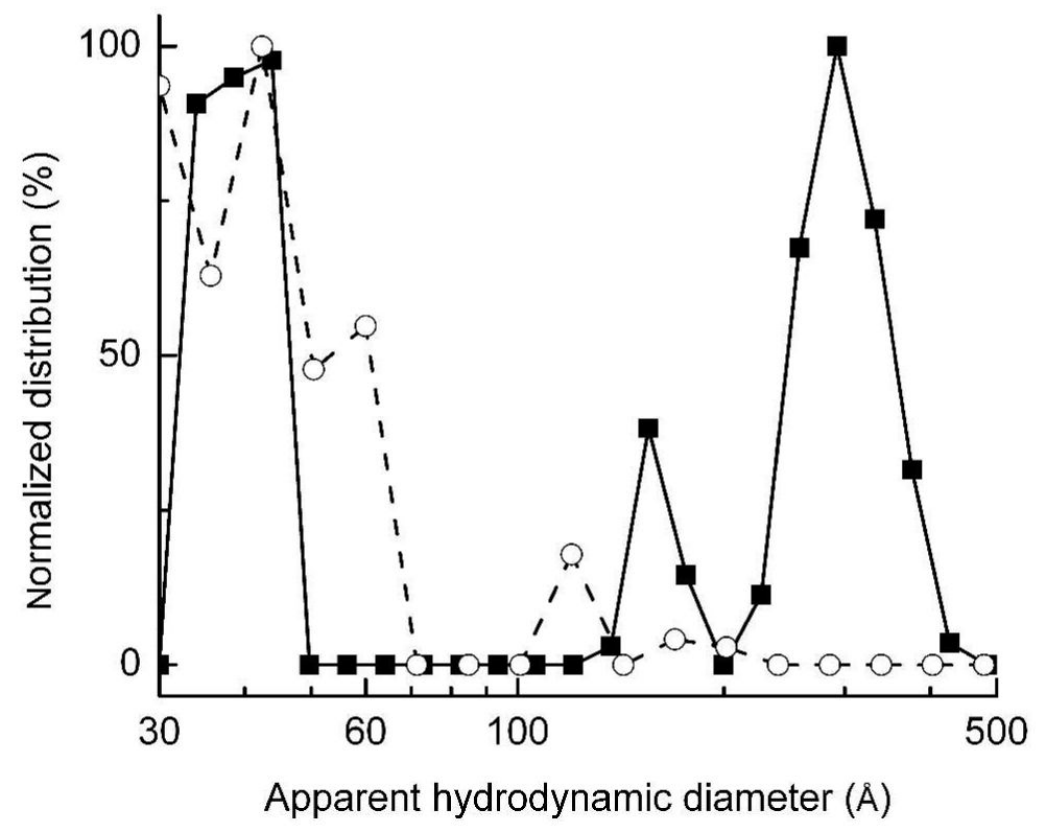

Figure 9.

Dynamic light scattering of the NMR samples of (o) NP2-ImH (pH 7.0) and (ש) wt NP7-ImH $\left(\mathrm{pH}^{*} 5.5\right)$ reported in Figure 7. The normalized Rayleigh scattering was plotted $v s$. the logarithm of the apparent hydrodynamic diameter. 


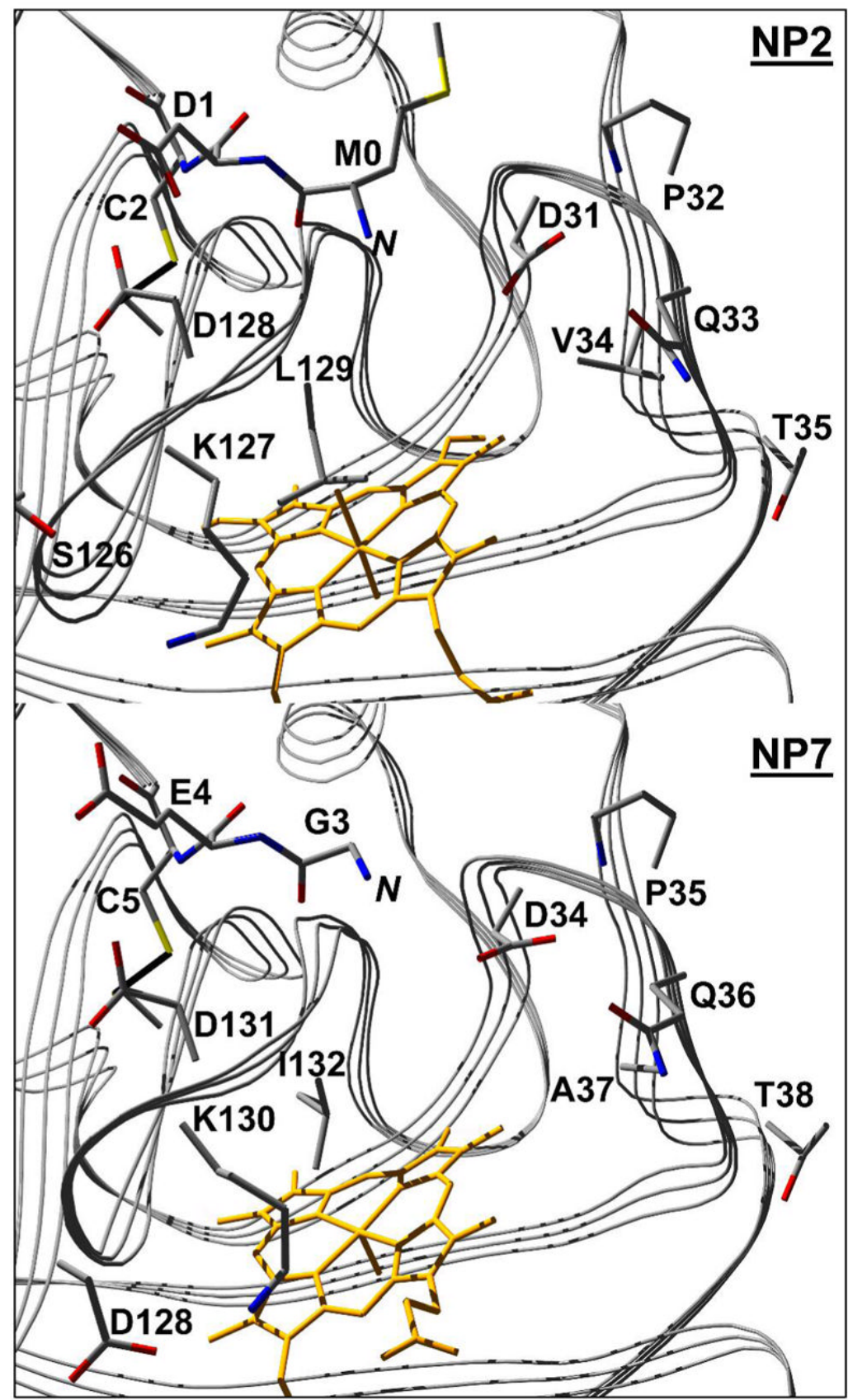

Figure 10.

Comparison of the structural environment of the N-terminus of NP2 (PDB code 1EUO) (top) with the homology model of NP7(G3-S182) (bottom). The residue numbering is according to Figure 1. Displayed are the heme cofactor (amber), the N-terminus (residues Met- 0 to Cys-2, NP2; Gly-3 to Cys-5, NP7), the A-B loop (residues Asp-31 to Thr-35, NP2; Asp-34 to Thr-38, NP7), and the G-H loop (residues Gly-125 to Leu-129, NP2; Asp-128 to Ile-132, NP7). Figures were prepared with DEEPVIEw V3.7 and rendered with POV-RAY V3.6 (http://www.povray.org). 


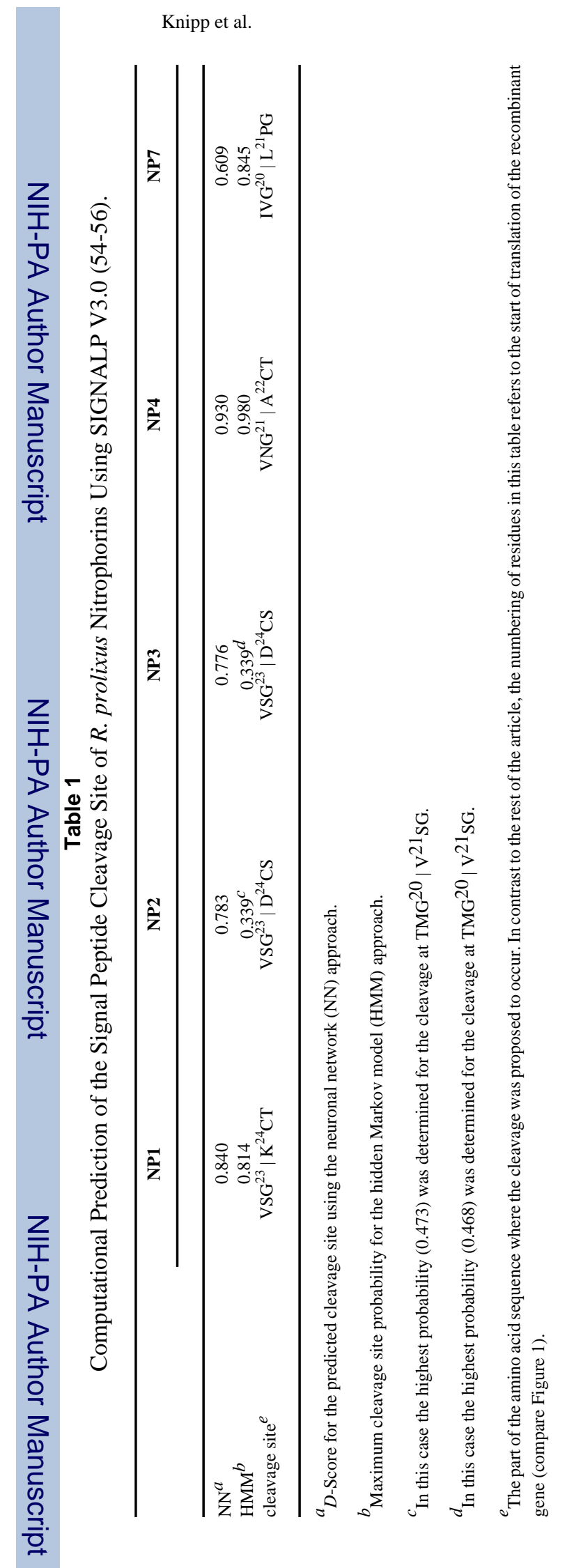

Biochemistry. Author manuscript; available in PMC 2008 November 20. 
Knipp et al.

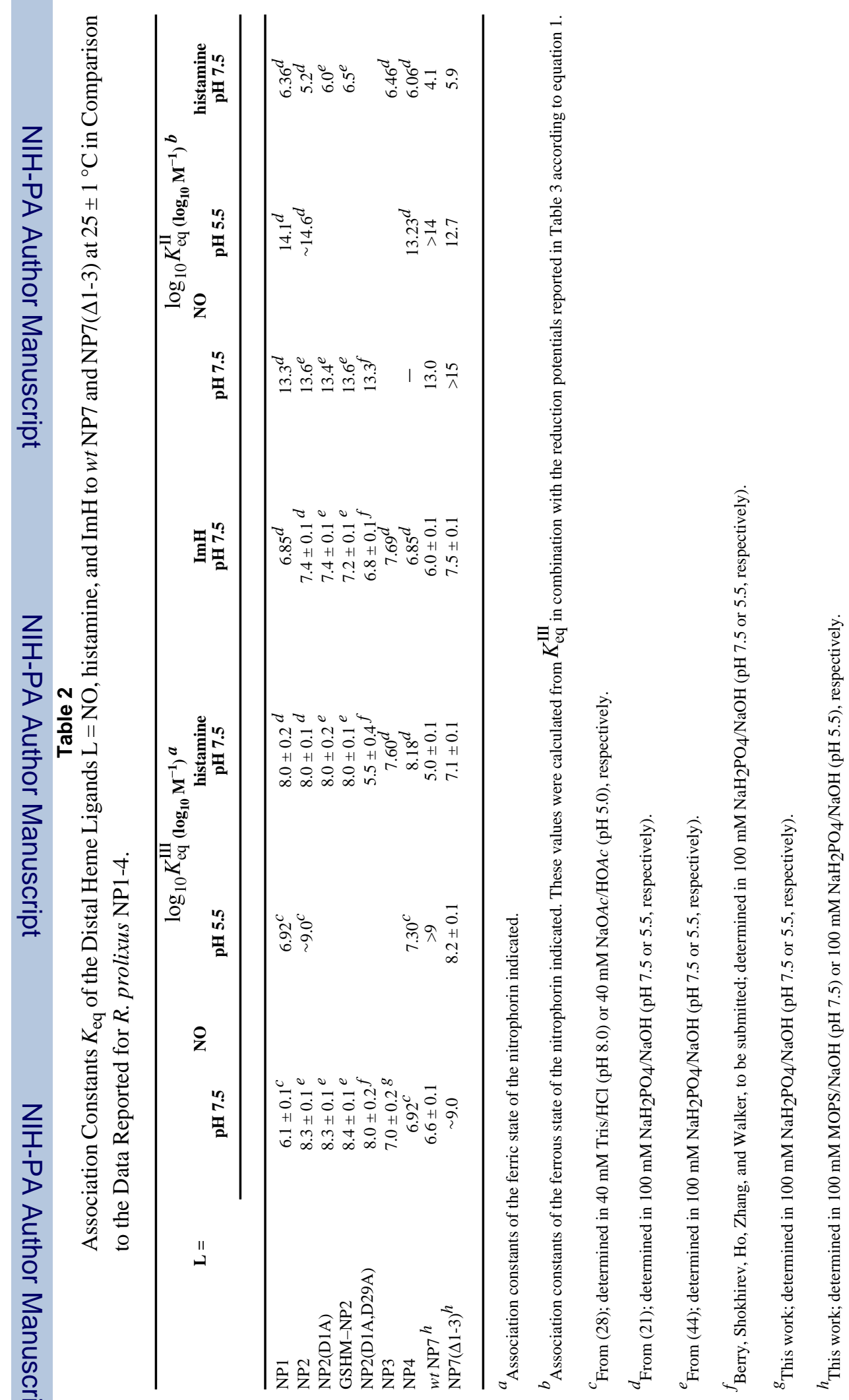

Biochemistry. Author manuscript; available in PMC 2008 November 20. 


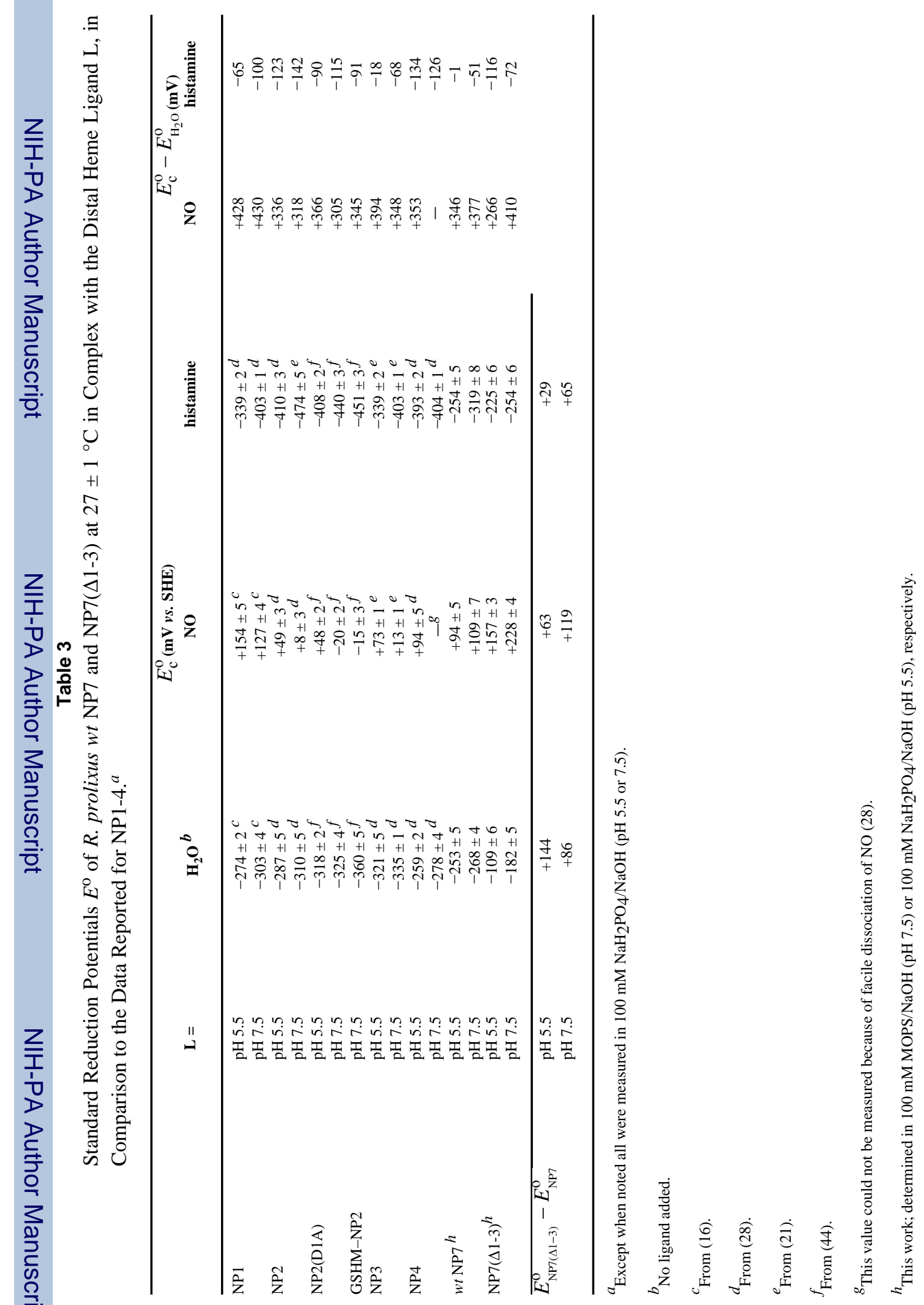


Table 4

Kinetic Parameters for NO Binding to Ferric R. prolixus wt NP7 and NP7( $\Delta 1-3)$ in Comparison to NP1-4 at high pH.

\begin{tabular}{lcc}
\hline & $\boldsymbol{k}_{\text {off }}\left(\mathbf{s}^{-\mathbf{1}}\right)$ & $\boldsymbol{k}_{\mathbf{\text { on }}}\left(\mathbf{1 0}^{\mathbf{6}} \mathbf{M}^{\mathbf{- 1}} \mathbf{s}^{\mathbf{- 1}}\right)$ \\
\hline $\mathrm{NP}^{a}$ & $2.2 \pm 0.1$ & $1.5 \pm 0.1$ \\
$\mathrm{NP}{ }^{a}$ & $0.12 \pm 0.01$ & 33 \\
$\mathrm{NP}^{b}$ & $0.08 \pm 0.01$ & 6.7 \\
$\mathrm{NP}^{a}$ & $2.6 \pm 0.1$ & 2.3 \\
$w \mathrm{NP}^{c}$ & $0.606 \pm 0.13$ & $2.4^{d}$ \\
$\mathrm{NP} 7(\Delta 1-3)^{c}$ & $0.50 \pm 0.02$ & $\sim 500^{d}$ \\
\hline
\end{tabular}

$a_{\text {Determined in }} 40 \mathrm{mM}$ Tris/ $\mathrm{HCl}(\mathrm{pH} 8.0)$ at $25^{\circ} \mathrm{C}$; taken from (28) where $k_{\mathrm{Off}}$ is referred to as the fast rate $k_{\mathrm{Off} 1}$ and $k_{\text {on }}$ as the fast rate $k_{1}$.

$b_{\text {Determined in }} 40 \mathrm{mM}$ Tris/ $\mathrm{HCl}(\mathrm{pH} 8.0)$ at $12{ }^{\circ} \mathrm{C}$; taken from (28) where $k_{\mathrm{Off}}$ is referred to as the fast rate $k_{\mathrm{Off}} 1$ and $k_{\mathrm{O}}$ as the fast rate $k_{1}$.

$c^{c}$ Determined in $100 \mathrm{mM}$ MOPS/ $\mathrm{NaOH}(\mathrm{pH} 7.5)$ at $25 \pm 1^{\circ} \mathrm{C}$; this work.

$d_{\text {Calculated from } K_{\text {eq }}=k_{\text {on }} / k_{\text {off }} \text { where }} K_{\text {eq }}^{\text {III }}$ was taken from Table 2. 